\title{
Mediterranean Outflow and surface water variability off southern Portugal during the early Pleistocene: A snapshot at Marine Isotope Stages 29 to 34 (1020-1135 ka)
}

\author{
Antje H.L. Voelker ${ }^{\mathrm{a}, *}$, Emilia Salgueiro ${ }^{\mathrm{a}, \mathrm{b}}$, Teresa Rodrigues ${ }^{\mathrm{a}, \mathrm{b}}$, Francisco J. Jimenez-Espejo ${ }^{\mathrm{c}}$, André Bahr ${ }^{\mathrm{d}, 1}$, \\ Ana Alberto ${ }^{a}$, Isabel Loureiro ${ }^{\mathrm{a}}$, Maria Padilha ${ }^{\mathrm{a}}$, Andreia Rebotim ${ }^{\mathrm{a}, \mathrm{b}, \mathrm{e}}$, Ursula Röhl ${ }^{\mathrm{e}}$ \\ a Divisão de Geologia e Georecursos Marinhos, Instituto Português do Mar e da Atmosfera (IPMA), Avenida de Brasília 6, Lisboa 1449-006, Portugal \\ b CCMAR Associated Laboratory, University of the Algarve, Campus de Gambelas, Faro 8005-139, Portugal \\ c Department of Biogeochemistry, Japan Agency for Marine-Earth Science and Technology (JAMSTEC), 2-15 Natsushima, Yokosuka 237-0061, Japan \\ ${ }^{\mathrm{d}}$ Institute of Geosciences, Goethe University, Altenhöferallee 1, Frankfurt am Main 60438, Germany \\ e MARUM-Center of Marine Environmental Sciences, University of Bremen, Leobener Strasse, Bremen 28359, Germany
}

\section{A R T I C L E I N F O}

\section{Article history:}

Received 11 March 2015

Received in revised form 20 August 2015

Accepted 25 August 2015

Available online 3 September 2015

\section{Keywords:}

IODP Site U1387

Mediterranean Outflow

Interglacial MIS 31

Contourite layers

Insolation

Sea-surface temperature

Expedition 339

\begin{abstract}
A B S T R A C T
Centennial-to-millennial scale records from IODP Site U1387, drilled during IODP Expedition 339 into the Faro Drift at $558 \mathrm{~m}$ water depth, now allow evaluating the climatic history of the upper core of the Mediterranean Outflow (MOW) and of the surface waters in the northern Gulf of Cadiz during the early Pleistocene. This study focuses on the period from Marine Isotope Stages (MIS) 29 to 34, i.e. the interval surrounding extreme interglacial MIS 31. Conditions in the upper MOW reflect obliquity, precession and millennial-scale variations. The benthic $\delta^{18} \mathrm{O}$ signal follows obliquity with the exception of an additional, smaller $\delta^{18} \mathrm{O}$ peak that marks the MIS 32/31 transition. Insolation maxima (precession minima) led to poor ventilation and a sluggish upper MOW core, whereas insolation minima were associated with enhanced ventilation and often also increased bottom current velocity. Millennial-scale periods of colder sea-surface temperatures (SST) were associated with short-term maxima in flow velocity and better ventilation, reminiscent of conditions known from MIS 3. A prominent contourite layer, coinciding with insolation cycle 100, was formed during MIS 31 and represents one of the few contourites developing within an interglacial period. MIS 31 surface water conditions were characterized by an extended period (1065-1091 ka) of warm SST, but SST were not much warmer than during MIS 33. Interglacial to glacial transitions experienced 2 to 3 stadial/interstadial cycles, just like their mid-to-late Pleistocene counterparts. Glacial MIS 30 and 32 recorded periods of extremely cold $\left(<12{ }^{\circ} \mathrm{C}\right)$ SST that in their climatic impact were comparable with the Heinrich events of the mid and late Pleistocene. Glacial MIS 34, on the other hand, was a relative warm glacial period off southern Portugal. Overall, surface water and MOW conditions at Site U1387 show a strong congruence with Mediterranean climate, whereas millennial-scale variations are closely linked to North Atlantic circulation changes.
\end{abstract}

(c) 2015 Elsevier B.V. All rights reserved.

\section{Introduction}

Within the longer cooling trend starting around $1800 \mathrm{ka}$ (McClymont et al., 2013), MIS 31, which received the highest intensity summer insolation $\left(567 \mathrm{~W} / \mathrm{m}^{2}\right)$ of the last $1800 \mathrm{ky}$ (Laskar et al., 2004), stands out as a long lasting interglacial period that in many regions experienced surface water temperatures as warm as late Pleistocene interglacial MIS 5e, 9e or 11c (Medina-Elizalde and Lea, 2005; McClymont et al., 2008; Lawrence

\footnotetext{
* Corresponding author.

E-mail address: antje.voelker@ipma.pt (A.H.L. Voelker).

1 Now at: Institute of Earth Sciences, Heidelberg University, Im Neuenheimer Feld 234, 69120 Heidelberg, Germany.
}

et al., 2010; Russon et al., 2011). Climate conditions were also exceptional, i.e. warmer than present, in the polar regions of the northern (Melles et al., 2012) and southern hemispheres (Scherer et al., 2008; Naish et al., 2009; Teitler et al., 2015) with a significantly reduced Antarctic ice volume (Scherer et al., 2008). Atmospheric carbon dioxide concentrations (Hönisch et al., 2009; Tripati et al., 2009) were comparable with those of the warm late Pleistocene interglacials supporting the idea that MIS 31 can be included in the pool of interglacial periods to be studied to better understand interglacial climate diversity (Tzedakis et al., 2009) and to potentially predict the future evolution of the current interglacial period, the Holocene.

MIS 31 occurred during the early phase of the mid-Pleistocene Transition, which lasted from 1250 to 700 ka (Clark et al., 2006). The mid- 
Pleistocene Transition is associated with a shift, centered around $922 \pm$ $12 \mathrm{ka}$ (Mudelsee and Schulz, 1997), from a dominant $41 \mathrm{ky}$ (obliquity) to a 100 ky (eccentricity) climate cycle. Besides obliquity, most earlyto-mid Pleistocene deep-sea records also exhibit climate cycles at the precession (23 ky) frequency (e.g., Girone et al., 2013; McClymont et al., 2013). Studies of surface and deep-water properties at centennial-scale resolution furthermore revealed millennial-scale variability, in particular during glacial periods (Hodell et al., 2008; Weirauch et al., 2008; Hernández-Almeida et al., 2012). The millennial-scale cycles ( 11 ky; $\sim 5 \mathrm{ky}$ ) are interpreted as harmonics of the precessional cycle (Weirauch et al., 2008; Ferretti et al., 2010; Billups and Scheinwald, 2014). In the Mediterranean Sea, precession plays an important role in modulating climate because of its influence on the African monsoon system. Associated with precession minima (insolation maxima) organicrich sapropel layers were formed in particular in the eastern Mediterranean Sea (e.g., Rossignol-Strick, 1985; Emeis et al., 2000). Sapropel formation is linked to enhanced freshwater fluxes and temperature and salinity stratification, all of which inhibited convection and led to poor ventilation and even anoxic conditions in the deeper water column (e.g., Rohling and Gieskes, 1989; Emeis et al., 2003; Schmiedl et al., 2003; de Lange et al., 2008). Reduced convection directly affects the intermediate-to-deep water masses contributing to the deep outflow from the Mediterranean Sea that is feeding the MOW in the Gulf of Cadiz and a "gap" in Holocene contourite layers in the Gulf of Cadiz has been linked to the formation of sapropel 1 (Rogerson et al., 2012). Borehole records of Pliocene sediments in the Gulf of Cadiz also show a strong response to precession forcing, here related to rainfall patterns in the southern Spain (Sierro et al., 2000).

Prior to IODP Expedition 339 paleoceanographic evidence on MOW variations in the Gulf of Cadiz was limited mainly to the last glacial-interglacial cycle (Sierro et al., 1999; Rogerson et al., 2005; Voelker et al., 2006; Toucanne et al., 2007), although seismic profiles across the contourite drifts pointed to MOW activity at least throughout the Quaternary (e.g., Llave et al., 2001; Hernández-Almeida et al., 2012). Highresolution studies over the last $50 \mathrm{ky}$ revealed that flow velocity of both MOW cores varied over time and changed synchronously with the abrupt climate change events in the North Atlantic. Velocity in both cores increased during the cold climate periods (Greenland stadials) of MIS 2 and MIS 3 (Llave et al., 2006; Voelker et al., 2006; Toucanne et al., 2007). On the glacial-interglacial timescale, however, the upper MOW is perceived to be stronger during interglacial periods and the lower core during glacial periods (Rogerson et al., 2005; Llave et al., 2006). To fully assess the spatial and temporal MOW variability therefore requires a dense set of sedimentary records from different water depths within the Gulf of Cadiz. The recovery of long sediment sequences from the contourite drifts formed by the MOW along the southern Iberian margin during IODP Expedition 339 (Stow et al., 2013; Hernández-Molina et al., 2014) now allows examining the dynamics of the different MOW cores on orbital and millennial time-scales. In the current study we are using sediments from IODP Site U1387 (Fig. 1a) to specifically evaluate the upper MOW's response to climate change during the early Pleistocene focusing on the glacial-interglacial
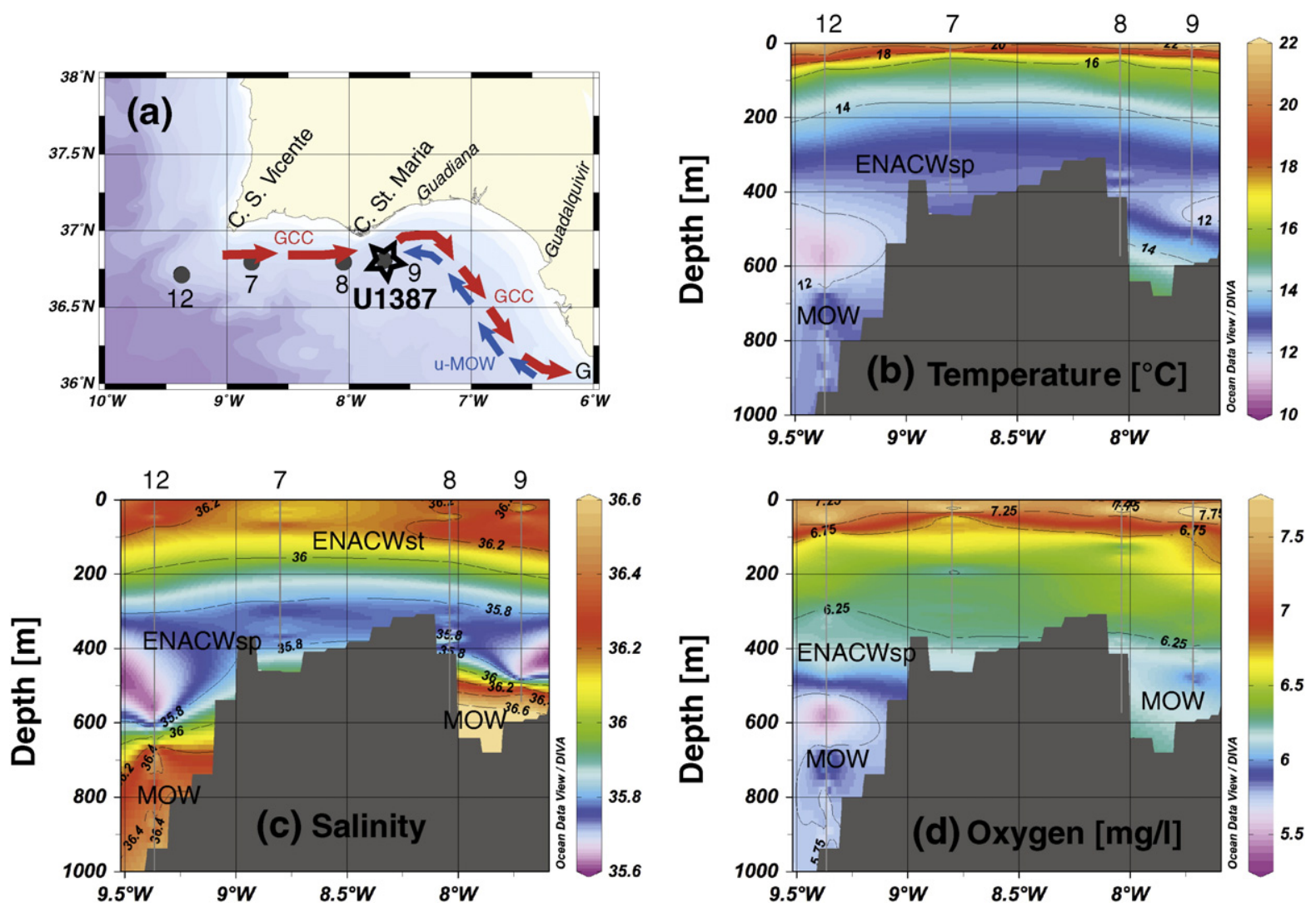

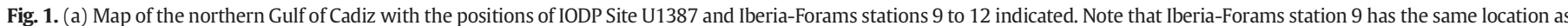

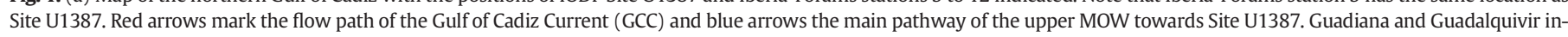

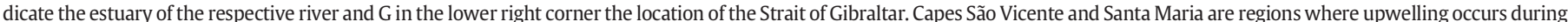

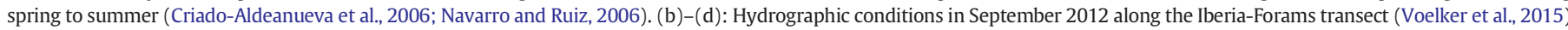

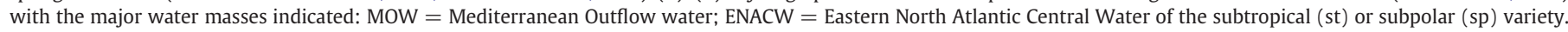
Figures were made with the Ocean Data View (ODV) software (Schlitzer, 2014). 
cycles of MIS 29 to MIS 34. While single-site data necessarily provides limited insights into the spatial MOW variability, our data clearly documents a highly dynamic MOW over this critical time interval, acting in concert with high and low latitude forcing.

\section{Regional and hydrographic setting}

IODP Site U1387 $\left(36.8^{\circ} \mathrm{N} ; 7.7^{\circ} \mathrm{W}\right)$ was drilled with D/V JOIDES Resolution into the Faro drift at a water depth of $559 \mathrm{~m}$ (Stow et al., 2013). Activity of the upper MOW branch, which as Mediterranean undercurrent acts like a contour current (Ambar et al., 1999; Bower et al., 2002), is building up the Faro drift on the middle slope of the southern Portuguese margin since the Pliocene (Roque et al., 2012; Hernández-Molina et al., 2014).

The MOW, also referred to as Atlantic Mediterranean Water, is the dominant water mass at intermediate depths in the Gulf of Cadiz. Due to differential mixing between the warm, saline Mediterranean Water, exiting from the Mediterranean Sea as deep overflow through the Strait of Gibraltar (main sill depth of $280 \mathrm{~m}$ ), and the overlying less dense Eastern North Atlantic Central Water (ENACW), the MOW forms two branches: an upper core between 500 and $800 \mathrm{~m}$ and a more saline, denser lower core between 1000 and 1400 m (Ambar and Howe, 1979; Baringer and Price, 1997). The upper MOW incorporates a shallow, third core with a mean depth of $500 \mathrm{~m}$ that can be observed along the southern Iberian margin (Ambar, 1983; Ambar et al., 2002). This shallow core was also encountered at the position of Site U1387 during the Iberia-Forams cruise in September 2012 (Fig. 1b-d; Voelker et al., 2015). Although the water masses contributing to the MOW are relatively young, oxygen content in the MOW is lower than in the overlying ENACW or underlying North Atlantic Deep Water (Fig. 1d; Ambar et al., 2002; Cabeçadas et al., 2002).

The deep outflow from the Mediterranean Sea consists of varying degrees of intermediate (Levantine Intermediate Water, LIW) and deep water masses (Western Mediterranean Deep Water, WMDW; Tyrrhenian Dense Water) (Kinder and Parrilla, 1987; Candela, 2001; Millot et al., 2006). These water masses are mostly formed by deep convection in regions such as the southern Adriatic Sea, the southern Aegean Sea, the Levantine Basin (all three for LIW) and the Gulf of Lions (for WMDW), where outbursts of cold, dry air from the European continent cool the surface waters during winter (Candela, 2001). In the geological past, however, deep convection and thus ventilation of the deeper water column was greatly diminished during the periods when sapropels were formed, in particular in the eastern basin where the LIW is formed.

The ENACW that is entrained into the MOW in the Gulf of Cadiz can have two origins. The subpolar variety $\left(\mathrm{ENACW}_{\mathrm{sp}}\right)$, formed by winter convection in the vicinity of the Rockall Plateau (Brambilla et al., 2008), is encountered between 250 and $500 \mathrm{~m}$ water depth along the western Iberian margin and clearly marked by a salinity minimum between 450 and $500 \mathrm{~m}$ (Fig. 1c; Fiuza et al., 1998; Voelker et al., 2015). The subtrop-

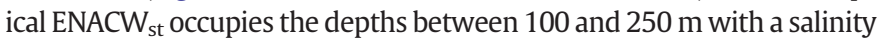
maximum around $100 \mathrm{~m}$ (Fig. 1c; Fiuza et al., 1998; Voelker et al., 2015). This water mass is formed by winter convection along the Azores Front and advected to the Iberian margin as subsurface component of the eastern Azores Current branch (Rios et al., 1992; Peliz et al., 2005). In the offshore region of the Gulf of Cadiz and at water depths closer to the lower MOW core remnants of Antarctic Intermediate Water (AAIW) have been detected (Cabeçadas et al., 2002; Louarn and Morin, 2011; Voelker et al., 2015), whereas the deepest parts of the basin are filled with North Atlantic Deep Water.

Surface waters in the Gulf of Cadiz, mostly originating from the North Atlantic's subtropical gyre, are transported by two dominant currents, the eastern branch of the Azores Current and the Gulf of Cadiz Slope Current (GCC) (Peliz et al., 2005, 2007; Garcia-Lafuente et al., 2006). The meandering Azores Current branch feeds the offshore Atlantic inflow to the Mediterranean Sea, whereas the GCC flows as an open ocean surface to upper slope current along the southern Iberian margin from Cape São Vicente towards the Strait of Gibraltar (Peliz et al., 2009). The GCC is therefore the current directly influencing the location of IODP Site U1387 (Fig. 1a). During the upwelling season (May-September) the GCC can also advect waters upwelled in the Cape São Vicente filament. The shape and direction of the highly productive Cape São Vicente filament are very variable, but its most persistent feature is an eastward extension along the southern shelf break and slope of Portugal (Sousa and Bricaud, 1992; Relvas and Barton, 2002). With westerly winds a local upwelling plume also forms off Cape Santa Maria (Criado-Aldeanueva et al., 2006; Navarro and Ruiz, 2006), i.e. in the vicinity of Site U1387 (Fig. 1a), and sometimes high pigment concentrations can be observed in a coastal band extending from Cape São Vicente as far as the Strait of Gibraltar (Sousa and Bricaud, 1992).

\section{Material and methods}

In the studied interval the shipboard splice joins core sections from Holes U1387A and U1387B (Expedition 339 Scientists, 2013) (Fig. 2).

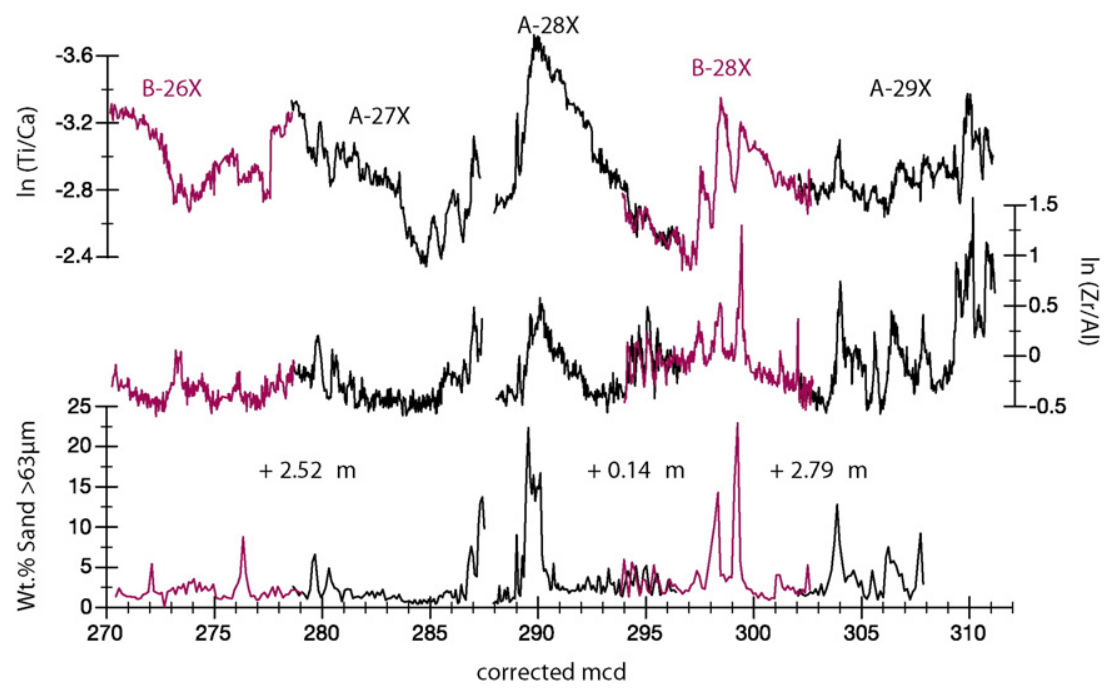

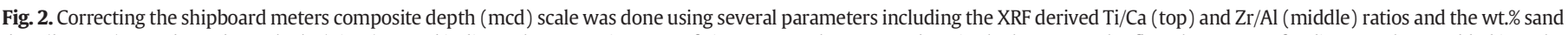

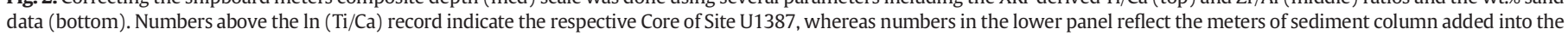
splice. No adjustments were made for compression/extension of sediments at the splice transitions what can result in minor offsets between the records. 
For the discrete analyses, the sections were sampled at a spacing of 12 to $13 \mathrm{~cm}$, except for sections U1387A-27X-5 to -CC and U1387A-28X-1 to -4 where the sample resolution was increased to $8 \mathrm{~cm}$. Each sample interval had a width of $2 \mathrm{~cm}$ yielding a volume of 20 to $30 \mathrm{~cm}^{3}$. At levels where geochemical analyses were planned, the initial sample was subsampled prior to laboratory treatments. All the Site U1387 data are
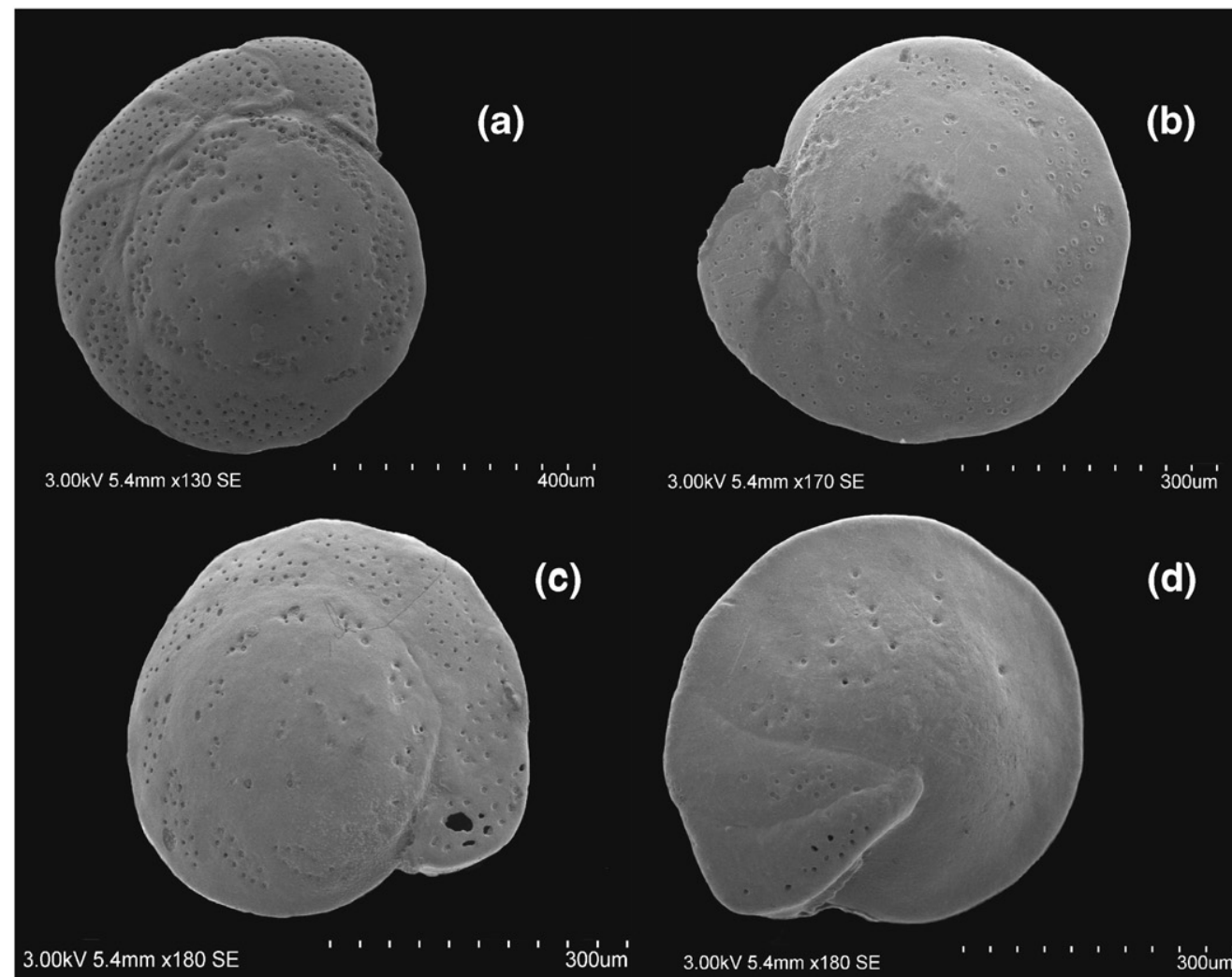

(d)

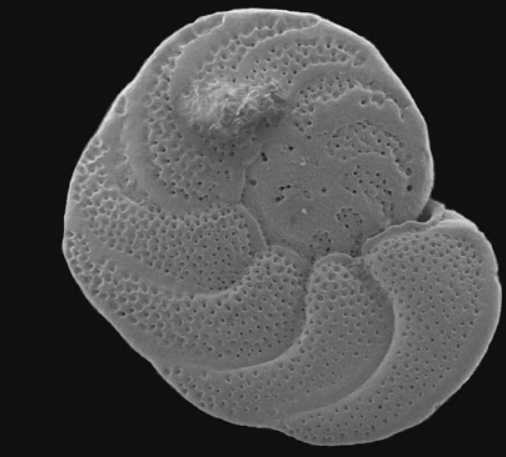

(e)

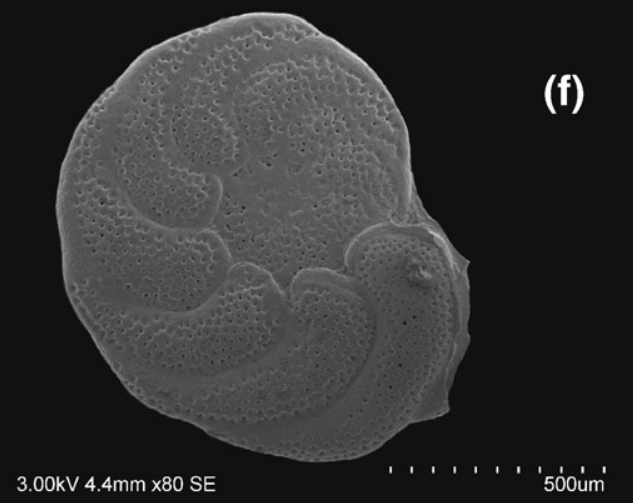

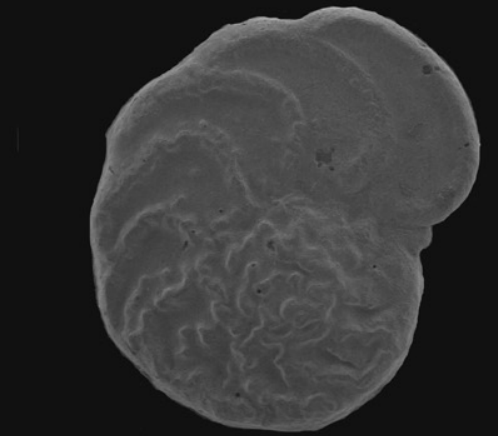

$3.00 \mathrm{kV} 5.4 \mathrm{~mm} \times 130 \mathrm{SE}$
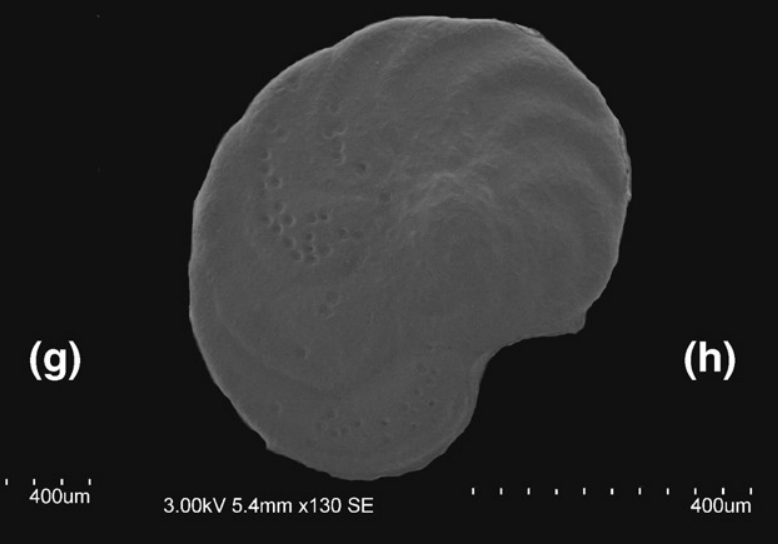

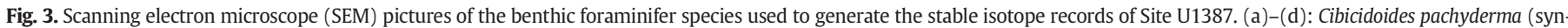

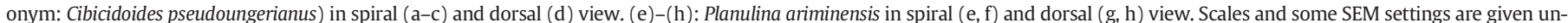
derneath each picture. Specimens shown are from Cores U1387A-19X, U1387A-28X and U1387B-20X. 
publicly available from the PANGAEA Data Center via the parent link http://doi.pangaea.de/10.1594/PANGAEA.848409. The Iberia-Forams hydrographic data can be accessed through http://doi.pangaea.de/10. 1594/PANGAEA.831461.

\subsection{Sample preparation and grain size analysis}

Sample preparation for the foraminifer and grain size studies followed the established procedures of the Sedimentology and Micropaleontology Laboratory of the Division for Geology and Marine Georesources (LSM-DivGM) of IPMA (formerly LNEG). Prior to and after freeze-drying the samples were weighted to obtain the wet and dry weights, respectively. The freeze-dried sample was washed with water through a $63 \mu \mathrm{m}$-mesh and the coarse fraction residue was dried in filter paper at $40{ }^{\circ} \mathrm{C}$ and weighted. The weight of the fraction $>63 \mu \mathrm{m}$ was used to calculate the weight-percent (wt.\%) of the sand in each sample ([weight $>63 \mu \mathrm{m} /$ dry weight] $* 100$ ).

During the washing the fraction $<63 \mu \mathrm{m}$ was collected for grain-size measurements. The grain-size data presented here was obtained on the total fine fraction following (Flood and Ducassou, submitted; Voelker et al., 2006). Prior to analysis, the organic matter was removed using hydrogen peroxide and the excess reagent was then eliminated using a $60{ }^{\circ} \mathrm{C}$ warm water bath and by washing the sample with distilled water through diatom ceramic candles. Prior to the grain-size analysis in the LSM-DivGM's Micrometrics Sedigraph 5100 each sample was homogenized by stirring. Values presented reflect the mean grain size of the total fine fraction (2-63 $\mu \mathrm{m})$ and are mostly based on two to three measurements.

\subsection{Organic sediment geochemistry parameters}

For the determination of the total organic carbon $\left(\mathrm{C}_{\mathrm{org}}\right)$ and total organic nitrogen (for $\mathrm{C} / \mathrm{N}$ ) contents of the sediment, aliquots $(2 \mathrm{mg}$ ) of dried and homogenized sediments were analyzed in the CHNS-932 LECO elemental analyzer of LNEG's Sedimentology and Micropaleontology lab. In a second step, aliquots of those same samples were burnt at $400{ }^{\circ} \mathrm{C}$ in an oven (destroying the organic carbon) and then analyzed again in the LECO elemental analyzer to determine the inorganic carbon content. The wt.\% organic carbon was calculated from the difference between the total and the inorganic carbon concentration. The relative precision of repeated measurements of both samples and standards was 0.03 wt.\%. The inorganic carbon content obtained from the second analysis is also used to calculate the sample's carbonate content (see Section 3.3).

In a sample series of 24 to $25 \mathrm{~cm}$ spacing molecular lipid analyses were performed to obtain total alkenone, n-alkane and n-alcohol concentrations and to estimate sea-surface temperatures (SST). After freeze-drying the samples were prepared following the procedure outlined in Villanueva et al. (1997). The organic compounds were extracted by sonication using dichloromethane and the extracts hydrolyzed with $6 \%$ potassium hydroxide in methanol to eliminate interferences from wax esters. The neutral lipids were then extracted with hexane, evaporated to dryness under a $\mathrm{N}_{2}$ stream and finally, derivatized with bis(trimethylsilyl)trifluoroacetamide. The lipids were analyzed in the DivGM's Varian Gas chromatograph Model 3800 equipped with a septum programmable injector and a flame ionization detector (Rodrigues et al., 2011).

Alkenones are photosynthesized by coccolithophores, i.e. haptophytia algae. The total alkenone concentration is therefore interpreted as an indicator for phytoplankton productivity. Based on the alkenone unsaturation index $\mathrm{U}^{\mathrm{k}}{ }_{37}$ ' (Brassell et al., 1986) annual mean SSTs were calculated using the equation of Müller et al. (1998). The n-alkanes and n-alcohols are compounds of higher plant leaf waxes and thereby terrigenous proxies (Eglinton et al., 1962; Eglinton and Eglinton, 2008). They are transported to the ocean via river run-off or as aerosols by the wind (Eglinton and Eglinton, 2008).

\subsection{Inorganic sediment geochemistry parameters}

The third product of the analyses in the LECO element analyzer is the sediment's carbonate content. The wt.\% carbonate was calculated by multiplying the inorganic carbon concentration with the factor of 8.332.

Down-core records of variations in 31 elements were obtained from the archive half sections using X-ray fluorescence (XRF) scanning. The measurements, at a spacing of $3 \mathrm{~cm}$, were done with the AVAATECH Core Scanner II (Serial No. 2) of the MARUM Research Center at the University of Bremen (Germany) (Bahr et al., 2014). Prior to scanning the archive halves were covered with a $4 \mu \mathrm{m}$ thin SPEXCerti Prep Ultralene1 foil to avoid contamination and dehydration of the sediment. With a sampling time of $20 \mathrm{~s}$ data was collected over a $1.2 \mathrm{~cm}^{2}$ area during three separate runs using generator settings of 10,30 , and $50 \mathrm{kV}$, and currents of $0.2,1.0$, and $1.0 \mathrm{~mA}$, respectively. The data was acquired by a Canberra X-PIPS Silicon Drift Detector (Model SXD 15C-150-500) with $150 \mathrm{eV}$ X-ray resolution and the Canberra Digital Spectrum Analyzer DAS 1000. The scanner's Oxford Instruments 50 W XTF5011 X-ray tube uses rhodium $(\mathrm{Rh})$ as target material. Processing of the raw data spectra was done with the iterative least square software package from Canberra Eurisys (Bahr et al., 2014).

In the current study we are only using the $\ln (\mathrm{Ti} / \mathrm{Ca})$ and $\ln (\mathrm{Zr} / \mathrm{Al})$ records (Fig. 2). As shown by Bahr et al. (2014), the $\ln (\mathrm{Zr} / \mathrm{Al}$ ) data can be used as a semiquantitative indicator for bottom current velocity variations. The $\ln (\mathrm{Ti} / \mathrm{Ca})$ record, on the other hand, reflects changes in the contribution of biogenic ( $\mathrm{Ca}$ from the calcium carbonate shells of marine organisms) versus detrital (Ti from heavy minerals) components to the sediments (e.g., Hodell et al., 2013). The core catcher (CC) section of Core U1387A-27X was not scanned leading to a $38 \mathrm{~cm}$ long data gap relative to the records based on discrete samples.

\subsection{Stable isotope analyses}

For the stable isotope analysis in foraminiferal shell carbonate specimens of the selected species were collected from the fraction $>250 \mu \mathrm{m}$. For the planktonic foraminifer analyses 8-12 specimens of Globigerina bulloides were selected. For the benthic foraminifer records data from the two species Cibicidoides pachyderma and Planulina ariminensis (Fig. 3) needed to be combined. Both species belong to the epibenthos group, whereby $P$. ariminensis prefers an elevated habitat, especially at water depths within the upper MOW core layer, and C. pachyderma the bottom nepheloid layer (Schönfeld, 1997; Schönfeld, 2001, 2002). For each species 2-8 specimens were submitted for analysis.

All G. bulloides and some of the benthic foraminifer samples were measured in the Finnigan MAT 251 or 252 mass spectrometer that is coupled to an automated Kiel I carbonate preparation system, at MARUM (University Bremen, Germany). The mass spectrometers' long-term precision is $\pm 0.05 \%$ of $\delta^{13} \mathrm{C}$ and $\pm 0.07 \%$ or $\delta^{18} \mathrm{O}$ based on repeated analyses of internal (Solnhofen limestone) and external (NBS-19) carbonate standards. A second series of benthic foraminifer samples, in particular from the U1387A-27X-5 to U1387A-28X-4 interval, was analyzed at the Geozentrum Nordbayern of the University Erlangen (Germany). There the samples were measured in the Gasbench II connected to a ThermoFinnigan Five Plus mass spectrometer after reacting with $103 \%$ phosphoric acid at $70^{\circ} \mathrm{C}$. The samples were always analyzed together with at least the two internal standards, Solnhofen-2 and Erlangen-5, the latter of which has an isotopic range similar to the LSVEC standard. Sometimes, LSVEC was included as a third standard. Analytical reproducibility of all three standards was in the $1 \sigma$ range of $0.02-0.04$ for $\delta^{13} \mathrm{C}$ and $0.02-0.08$ for $\delta^{18} \mathrm{O}$. All values are reported in permil relative to $\mathrm{V}$-PDB.

According to Marchitto et al. (2014) both, C. pachyderma and $P$. ariminensis, precipitate their shell calcite close to equilibrium. The $\delta^{18} \mathrm{O}$ values of both species are perceived as indistinguishable and were therefore not corrected for the current study, even though the parallel measurements (Table 1 ) sometimes revealed $\delta^{18} \mathrm{O}$ differences 
Table 1

Comparison of stable isotope values of $C$. pachyderma and $P$. ariminensis.

\begin{tabular}{|c|c|c|c|c|c|}
\hline \multirow[t]{2}{*}{ Sample ID } & \multicolumn{2}{|c|}{ C. pachyderma } & \multicolumn{2}{|c|}{ P. ariminensis } & \multirow[t]{2}{*}{$\delta^{13} \mathrm{C}$ Difference } \\
\hline & $\delta^{18} \mathrm{O}$ & $\delta^{13} \mathrm{C}$ & $\delta^{18} \mathrm{O}$ & $\delta^{13} \mathrm{C}$ & \\
\hline U1387B-20X-4 $103 \mathrm{~cm}$ & 2.67 & 0.67 & 2.42 & 1.18 & 0.51 \\
\hline U1387B-20X-5 $64 \mathrm{~cm}$ & 2.16 & 0.75 & 2.67 & 1.26 & 0.51 \\
\hline U1387B-20X-6 $77 \mathrm{~cm}$ & 1.98 & 0.59 & 2.05 & 1.25 & 0.66 \\
\hline U1387A-21X-1 $52 \mathrm{~cm}$ & 2.60 & 1.02 & 2.76 & 1.31 & 0.29 \\
\hline U1387B-25X-3 $12 \mathrm{~cm}$ & 2.48 & 0.98 & 2.58 & 1.38 & 0.40 \\
\hline U1387A-26X-191 cm & 2.30 & 0.85 & 2.25 & 1.29 & 0.34 \\
\hline U1387A-27X-2 $112 \mathrm{~cm}$ & 2.34 & 0.58 & 2.60 & 0.89 & 0.31 \\
\hline U1387A-27X-5 $103 \mathrm{~cm}$ & 2.25 & 0.80 & 2.28 & 1.36 & 0.46 \\
\hline U1387B-31X-1 $114 \mathrm{~cm}$ & 2.12 & 0.63 & 2.11 & 0.81 & 0.18 \\
\hline U1387C-11R-7 $60 \mathrm{~cm}$ & 1.62 & 0.61 & 1.56 & 0.98 & 0.37 \\
\hline
\end{tabular}

Bold values mark those used to define the $+0.3 \%$ o correction.

outside of the $2 \sigma$ error range. The $\delta^{13} \mathrm{C}$ values of $P$. ariminensis reflect $\delta^{13} C_{\text {DIC }}$ of the ambient seawater (Keigwin, 2002), whereas $\delta^{13} \mathrm{C}$ of $C$. pachyderma can be offset from $\delta^{13} \mathrm{C}_{\text {DIC }}$ (McCorkle et al., 1997; Rathburn et al., 1996; Wilson-Finelli et al., 1998). To estimate the potential $\delta^{13} \mathrm{C}$ offset between both species we analyzed them in parallel in several samples (Table 1 ). The offset varies between 0.29 and $0.66 \%$; a relative large scatter that probably arises from the different environmental preferences of each species (see above). Three of the values cluster around $0.3 \%$ (listed in bold in Table 1 ) and we use this minimum value to correct (adding) the C. pachyderma $\delta^{13} \mathrm{C}$ values to the P. ariminensis level.

\subsection{Corrections to the shipboard splice and mcd-scale}

During the course of analyzing the sediment samples of Site U1387 it became quickly obvious that the shipboard splice based on the physical properties (Expedition 339 Scientists, 2013) was not correct. A corrected mcd (c-mcd) scale is therefore being generated for the interval of 170 to 408 mcd of Site U1387 (A. Voelker, unpublished data). The core-to-core transitions are mainly corrected based on the high-resolution XRF scanning records (Fig. 2) but also take all the other proxy records into account. Currently, no adjustments are being made for compression or extension of the sediment column.

The c-mcd scale of the interval presented in this paper already inherited a correction of +13.49 m until the start of Core U1387B26X. For the interval presented in this study the splice has been corrected in the following way (Fig. 2):

- U1387B-26X to U1387A-27X: add $2.52 \mathrm{~m}$ for a transition from U1387B-26X-7 into U1387A-27X-1

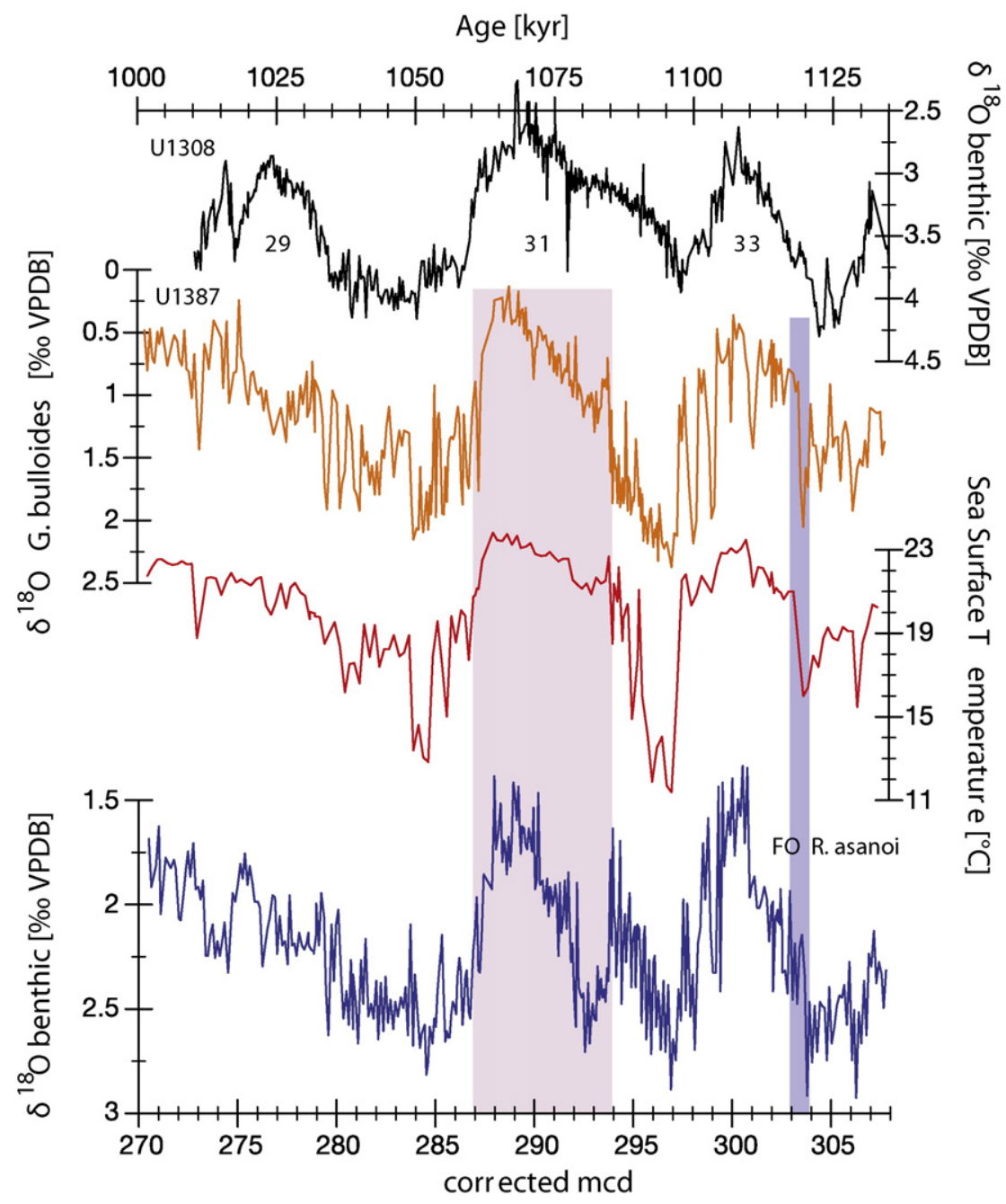

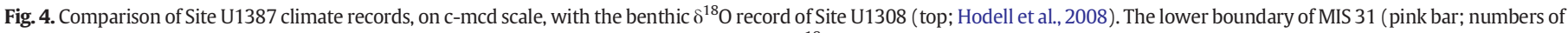

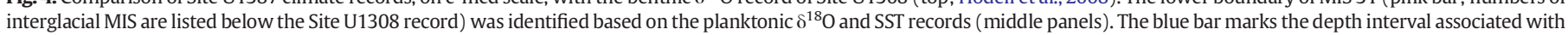
the First Occurrence (FO) of nannofossil species R. asanoi in Hole U1387A (Expedition 339 Scientists, 2013). 
- U1387A-28X to U1387B-28X: add $0.14 \mathrm{~m}$ for a transition from U1387A-28X-5 into 1387B-28X-2

- U1387B-28X to U1387A-29X: add $2.79 \mathrm{~m}$ for a transition from U1387B-28X-CC into U1387A-29X-1.

The latter transition is not ideal based on the sediment parameters shown in Fig. 2 but has a good fit in the planktonic and benthic stable isotope records.

Due to poor recovery for Core U1387B-27X, the splice appends Section U1387A-28X-1 to U1387A-27X-7 (Expedition 339 Scientists, 2013). We are including Section U1387A-27X-CC in this study, but cannot exclude that some sediment (time) might be missing at this splice transition (between 1066 and $1067.5 \mathrm{ka}$ ).

\subsection{Age model and sedimentation rates}

In general, the benthic and planktonic $\delta^{18} \mathrm{O}$ records of Site $\mathrm{U} 1387$ reveal clear glacial/interglacial cycles (Voelker et al., 2014). In the interval from MIS 31 to MIS 33, however, three benthic $\delta^{18} \mathrm{O}$ peaks were recorded (Fig. 4). The older peak can clearly be attributed to MIS 33 because of the nannofossil stratigraphic datum of the First Occurrence of Reticulofenestra asanoi. The depth of this event, which is recorded in Core U1387A-29X at 257.85-258.57 mbsf (Expedition 339 Scientists, 2013) (corresponding to 303.00-303.72 c-mcd), coincides with the beginning of MIS 33 (Fig. 4) and thus fits exactly the event's lower age range as defined by Raffi et al. (2006). For identifying the beginning of MIS 31 we relied on the planktonic $\delta^{18} \mathrm{O}$ and SST records assuming that the abrupt amelioration in

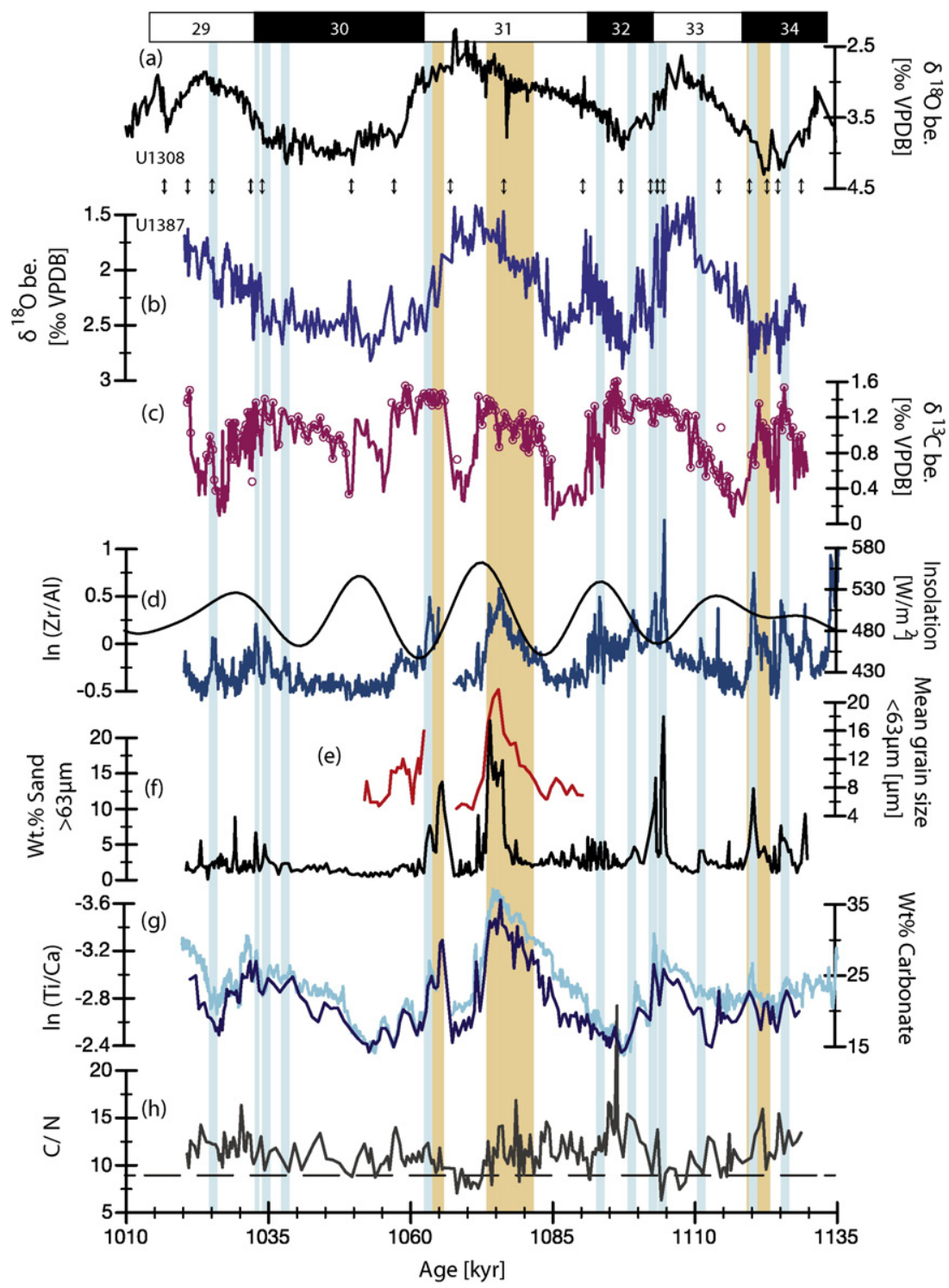

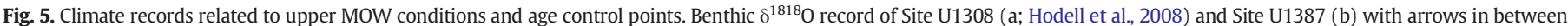

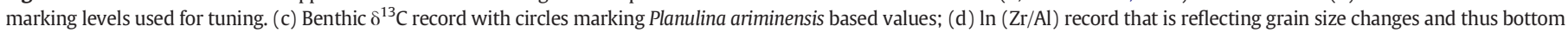

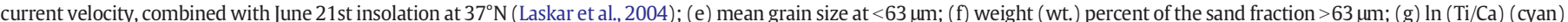

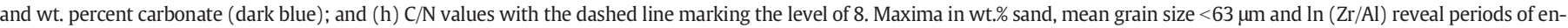

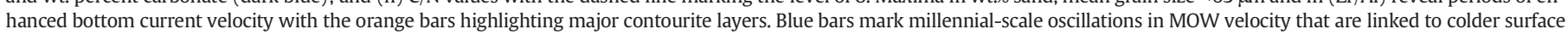
waters (see Fig. 6). Squares and numbers in the banner on top indicate the respective MIS. 


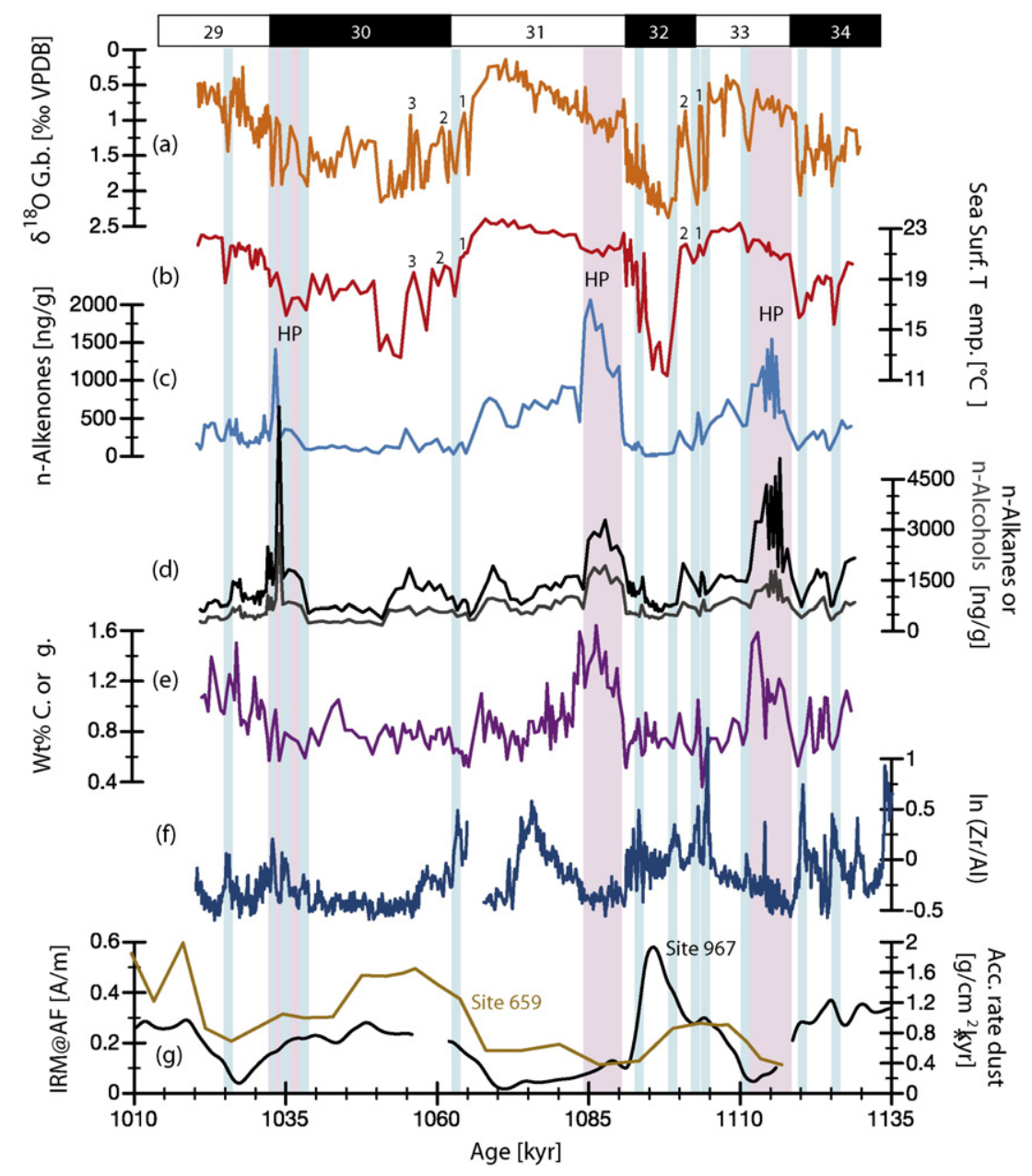

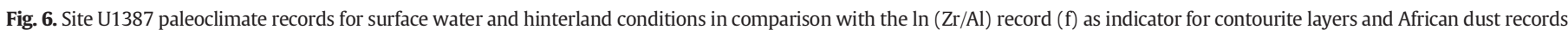

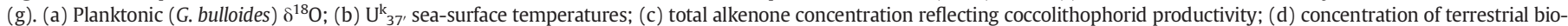

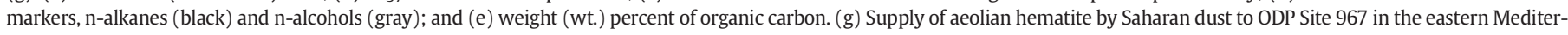

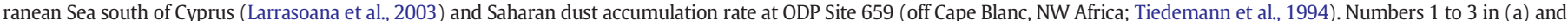

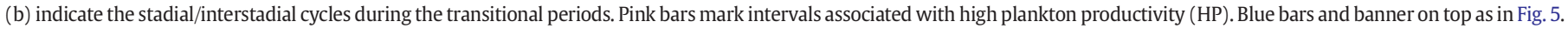

surface water conditions marked the initiation of interglacial climate conditions, similar to MIS 11 (Rodrigues et al., 2011; Voelker et al., 2010). Consequently, MIS 31 at Site U1387 incorporates the interval from 1062 to $1091 \mathrm{ka}$ (Fig. 5, 6), starting 10 ky earlier than defined by Lisiecki and Raymo (2005) but in agreement with the early strengthening in the Atlantic Meridional Overturning Circulation (AMOC) depicted in the high-resolution benthic $\delta^{13} \mathrm{C}$ record of Site U1308 (Fig. 7d; Hodell et al., 2008) and with the recently published stratigraphy of Portuguese margin Site U1385 (Hodell et al., 2015). The smaller benthic $\delta^{18} \mathrm{O}$ peak in the middle then belongs to MIS 32 (Figs. 4, 5).

The age model (Table 2) was established by tuning the benthic $\delta^{18} \mathrm{O}$ record of Site U1387 to the one of Site U1308 (Hodell et al., 2008) that has an age model linked to the LR04 stack (Lisiecki and Raymo, 2005). Primary tuning points were glacial maxima or onsets of transitions (deglaciation or glacial inception; Fig. 5a). Afterwards smaller oscillations were aligned. With this age model the U1387 planktonic and benthic $\delta^{18} \mathrm{O}$ records agree well with other records (e.g., U1385: Hodell et al., 2015; U1314: Hernández-Almeida et al., 2012; Fig. 7a) for the interval from MIS 30 to MIS 34. Caution should, however, be applied to the late MIS 29 period where the age model might have to be adjusted when a final correction becomes available for the splice transition from Core U1387A-26X into Core U1387B-26X and thus a clear identification of the MIS 29/28 boundary.
The sedimentation rates vary between 22 and $91 \mathrm{~cm} / \mathrm{ky}$ (Table 2) and agree well with the shipboard estimate of $25 \mathrm{~cm} / \mathrm{ky}$ as average Pleistocene sedimentation rate (Expedition 339 Scientists, 2013). With these rates the presented climate records have a temporal resolution of 300 to 500 years for the biomarker, organic carbon and carbonate data, of 130 (within MIS 31) to 400 years for the stable isotope and wt.\% sand data and of 40 to 160 years for the XRF-derived ratios.

\section{Results}

\subsection{Stable isotope results}

The planktonic and benthic $\delta^{18} \mathrm{O}$ records show clear glacial-interglacial cycles (Figs. 5b, 6a), although not with the same pattern. In general, the values of both records are offset by about $1 \%$. During glacial MIS 32 , however, this difference is greatly reduced and the records nearly converge. As to be expected for a warmer water mass like the MOW, the benthic $\delta^{18} \mathrm{O}$ values of Site $\mathrm{U} 1387$ are lower ( 1\%) than those recorded at North Atlantic Deep Water sites (such as U1308; Fig. 5a, b). Millennial-scale variability is also seen in the Site U1387 $\delta^{18} \mathrm{O}$ records. Whereas the planktonic record shows such variability during all three glacial stages (MIS 30, 32, 34), it is pronounced in the upper MOW record mostly during the transitions from MIS 33 to MIS 32 and MIS 30 to MIS 29 and during MIS 32 itself. Noteworthy here is in particular 


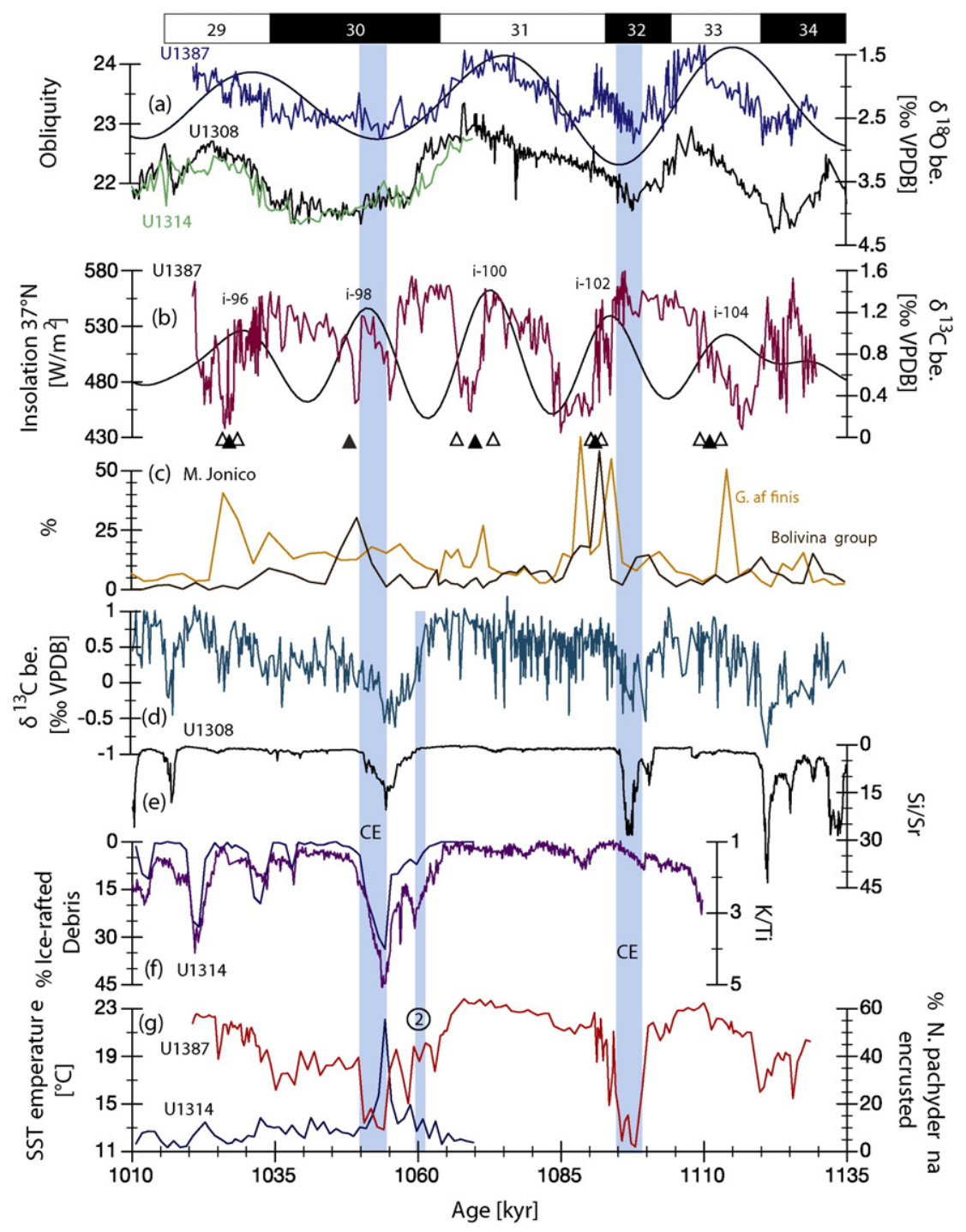

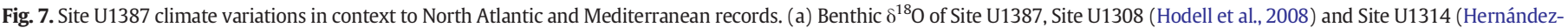

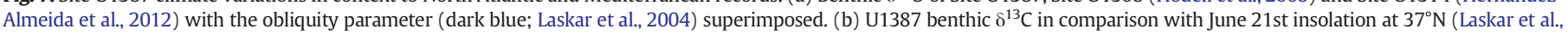

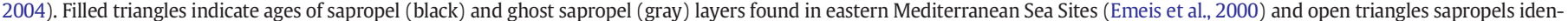

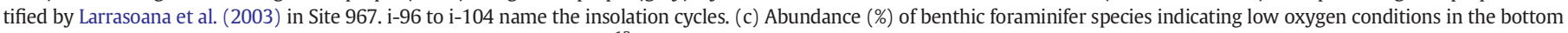

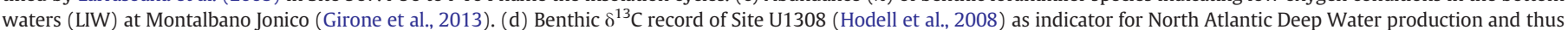

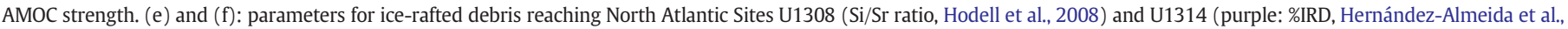

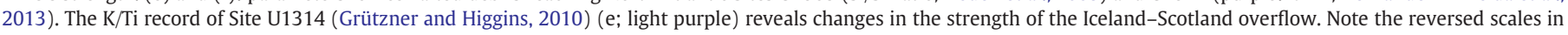

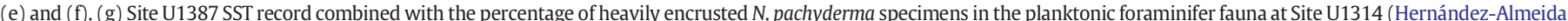

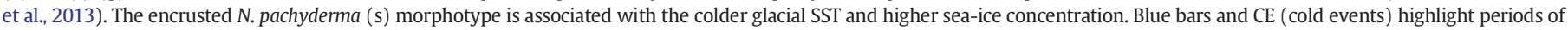
extremely cold SST at Site U1387. The shorter blue bar and the number 2 in (d) to (g) mark the potential additional stadial event (see Section 5.3). Banner on top as in Fig. 5.x

the benthic $\delta^{18}$ O peak (1088-1096 ka) coinciding with the transition from MIS 32 into MIS 31 (Fig. 5b).

The benthic $\delta^{13} \mathrm{C}$ record reveals cyclic variations between high and low values (Fig. 5c), corresponding with a well and a poorly ventilated water mass, respectively. Higher values are mostly based on analyses of the species $P$. ariminensis-a species that nowadays thrives within the upper MOW layer (Schönfeld, 2002)-clearly indicating that upper MOW conditions were recorded at Site U1387. Transitions from a well into a poorly ventilated state were often abrupt, whereas the reverse transition was often more gradual (Fig. 5c). Both, however, involved shifts of $\geq 0.7 \%$.

\subsection{Properties of contourite layers}

The interval from MIS 29 to MIS 34 includes several contourite layers (Fig. 5). These layers are clearly marked by the higher percentage of sand. Bottom current velocity gradually increased, however, already prior to the wt.\% sand maximum as revealed by the $\ln (\mathrm{Zr} / \mathrm{Al})$ and mean grain size $<63 \mu \mathrm{m}$ records. The $\ln (\mathrm{Zr} / \mathrm{Al})$ and mean grain size $<63 \mu \mathrm{m}$ records show the same trends (Fig. $5 \mathrm{~d}, \mathrm{e}$ ), confirming that the $\ln (\mathrm{Zr} / \mathrm{Al})$ data is tracking changes in current velocity (Bahr et al., 2014). Following the wt.\% sand peak, i.e. the period of strongest bottom flow, current velocity often dropped abruptly as shown in all proxy records.

Also the wt.\% carbonate and $\ln (\mathrm{Ti} / \mathrm{Ca})$, on reverse scale, records follow each other (Fig. $5 \mathrm{~g}$ ) corroborating that the Ti/Ca ratio is reflecting changes in the relative contribution of biogenic carbonate and detrital components to the sediments as previously observed by Hodell et al. (2013) for the southwestern Portuguese margin. Maxima in carbonate (minima in Ti/Ca) are associated with the contourite layers, in particular the wt.\% sand maxima. This clearly reflects the high concentration of foraminiferal shells and to a lesser extent also ostracods and mollusk shell 
Table 2

Age model control points and sedimentation rates.

\begin{tabular}{llll}
\hline Sample ID & Depth [c-mcd] & Age [ky] & Sedimentation rate $[\mathrm{cm} / \mathrm{ky}]$ \\
\hline U1387A-26X-2 $115 \mathrm{~cm}$ & 267.79 & 1017.5 & \\
U1387B-26X-1 $137 \mathrm{~cm}$ & 271.36 & 1021.6 & 87.07 \\
U1387B-26X-3 $39.5 \mathrm{~cm}$ & 273.39 & 1025.9 & 47.21 \\
U1387A-27X-1 $137 \mathrm{~cm}$ & 279.59 & 1032.7 & 91.18 \\
U1387A-27X-2 $63 \mathrm{~cm}$ & 280.35 & 1034.5 & 42.22 \\
U1387A-27X-4 $115 \mathrm{~cm}$ & 283.87 & 1050.2 & 22.42 \\
U1387A-27X-5 $127.5 \mathrm{~cm}$ & 285.50 & 1057.7 & 21.73 \\
U1387A-28X-1 $4 \mathrm{~cm}$ & 287.86 & 1067.6 & 23.84 \\
U1387A-28X-2 $96 \mathrm{~cm}$ & 290.28 & 1077.0 & 25.74 \\
U1387A-28X-5 $2 \mathrm{~cm}$ & 293.84 & 1090.9 & 25.61 \\
U1387B-28X-4 $15 \mathrm{~cm}$ & 296.91 & 1097.6 & 45.82 \\
U1387B-28X-4 $135 \mathrm{~cm}$ & 298.11 & 1102.8 & 23.08 \\
U1387B-28X-5 $77 \mathrm{~cm}$ & 299.03 & 1104.0 & 76.67 \\
U1387B-28X-5 $115 \mathrm{~cm}$ & 299.41 & 1105.0 & 38.00 \\
U1387A-29X-1 $12 \mathrm{~cm}$ & 302.07 & 1114.8 & 27.14 \\
U1387A-29X-2 $139 \mathrm{~cm}$ & 303.79 & 1120.2 & 31.85 \\
U1387A-29X-3 $113 \mathrm{~cm}$ & 305.03 & 1123.3 & 40.00 \\
U1387A-29X-4 $87 \mathrm{~cm}$ & 306.27 & 1125.2 & 65.26 \\
U1387A-29X-5 $76 \mathrm{~cm}$ & 307.66 & 1129.3 & 33.90 \\
\hline
\end{tabular}

fragments within these sections of the contourite layers that were associated with the highest current velocity, in agreement with previous observations (Faugères et al., 1984; Sierro et al., 1999). The C/N values (Fig. 5h) generally exceed 8 and show that the sediment's organic matter contained a significant contribution of terrestrial organic matter (Stein, 1991). With the exception of the contourite layer at the end of MIS 33, C/N values were generally higher during periods of higher current velocity (as reflected in the $\ln (\mathrm{Zr} / \mathrm{Al})$ data).

\subsection{Molecular biomarker records}

The alkenone-based SSTs (Fig. 6b) reached values of 22.0 to $23.8^{\circ} \mathrm{C}$ during the interglacial periods and minima as cold as $12.8^{\circ} \mathrm{C}$ and $11.9^{\circ} \mathrm{C}$ during early MIS 30 and MIS 32, respectively. Surface waters during glacial MIS 34 and late MIS 30 were significantly warmer $\left(\sim 18-19^{\circ} \mathrm{C}\right)$. Millennial-scale SST oscillations were recorded during the transitions from MIS 32 to MIS 31 and from MIS 31 into MIS 30.

The records of total alkenones, n-alkanes and n-alcohols concentrations show a similar pattern (Fig. 6c, d). Higher values, also of the wt.\% organic carbon (Fig. 6e), are generally associated with interglacial periods. Three periods with elevated values stand out: 1033-1040 ka, 1084-1090 ka and 1112-1116 ka, all of which coincided with the glacial/interglacial transition and/or the beginning of the interglacial stage.

\section{Discussion}

\subsection{Upper MOW variations on orbital time-scales}

Both the benthic $\delta^{18} \mathrm{O}$ and $\delta^{13} \mathrm{C}$ records show orbital-scale cycles with obliquity dominating the $\delta^{18} \mathrm{O}$ and precession (inverse to insolation) the $\delta^{13} \mathrm{C}$ signal (Fig. 7). The oddity in the pattern is the smaller $\delta^{18} \mathrm{O}$ peak marking the MIS $32 / 31$ transition, which is also detected in the LIW related benthic $\delta^{18} \mathrm{O}$ record from Montalbano Jonico (southern Italy) (Girone et al., 2013; supplementary Fig. 1). The peak occurred during an obliquity and precession minimum and thus during a period of enhanced North African monsoon precipitation and river runoff (Bosmans et al., 2015b; Tuenter et al., 2003). On the other hand, precession minima can cause lower summer precipitation in southern Europe (Bosmans et al., 2015b), conform with the more arid climate at Montalbano Jonico (Joannin et al., 2008) during the period of the MIS $32 / 31$ peak, and increased wind speeds over the Aegean Sea (Bosmans et al., 2015a), both of which would be favorable for LIW formation. Thus LIW formed in the Aegean Sea could be responsible for the $\delta^{18} \mathrm{O}$ peak that at Site U1387 was mostly associated with higher benthic $\delta^{13} \mathrm{C}$ and $\ln (\mathrm{Zr} / \mathrm{Al}$ ) values (Fig. 5c, d) indicating the presence of a well ventilated, sometimes faster flowing MOW. Nevertheless, more data are needed to fully understand the origin of this $\delta^{18} \mathrm{O}$ peak.

The precession forcing of the benthic $\delta^{13} \mathrm{C}$ record is not unexpected given the known relationship between insolation maxima and sapropel formation (lagging the insolation maximum by $3 \mathrm{ky}$ ) in the Mediterranean Sea (e.g., Emeis et al., 2000; Schmiedl et al., 2003). At Site U1387, declines of insolation maxima were associated with low benthic $\delta^{13} \mathrm{C}$ values (Fig. 7b) that indicate a poorly ventilated water mass. These periods, furthermore, coincided with finer sediments (low wt.\% sand and $\ln (\mathrm{Zr} / \mathrm{Al})$; Fig. 5d, f) pointing to a more sluggish bottom current. A more sluggish bottom current could indicate either the absence of MOW above Site U1387 or MOW being less dense and neutrally buoyant already in the vicinity of the Faro Drift. The latter scenario would agree with Singh et al. (2015) who deduce upper MOW presence at Site U1387 during the insolation maxima of MIS 5 and MIS 7 from their benthic foraminifer data.

For insolation cycles i-96 and i-100 the Site U1387 $\delta^{13} \mathrm{C}$ minima concurred with the formation of sapropel layers in the eastern Mediterranean Sea (Fig. 7b; Emeis et al., 2000; Larrasoana et al., 2003) and with suboxic conditions at the LIW level (Fig. 7c; Girone et al., 2013). Within age model error bars the same is true for the second $\delta^{13} \mathrm{C}$ minimum during i-98 (Fig. 7), when a ghost sapropel was observed at ODP Site 967 (Emeis et al., 2000) and low oxygen conditions at Montalbano Jonico (Girone et al., 2013). During cycle i-102 the Site U1387 shows a clear lag of the benthic $\delta^{13} \mathrm{C}$ minimum to the insolation maximum (Fig. 7b). The minimum also lasted longer than the period of sapropel formation in the eastern Mediterranean Sea (Emeis et al., 2000; Larrasoana et al., 2003) that coincided with the onset of the minimum at Site U1387. At Montalbano Jonico, on the other hand, the top of the sapropel was dated to $1088 \mathrm{ka}$ and the benthic foraminifers recorded variable, but always low oxygen conditions at the LIW level throughout the whole period of the $\delta^{13} \mathrm{C}$ minimum at Site U1387 (Fig. 7b; Girone et al., 2013). Thus also this minimum can clearly be linked to Mediterranean Sea conditions.

The situation is slightly different for i-cycle 104 when the benthic minimum and insolation maximum concurred and thus mostly preceded the eastern Mediterranean sapropel layer and the peak in LIW low oxygen conditions (Fig. 7). This period was associated with an insolation maximum (precession minimum) and obliquity maximum, both of which lead to more northward penetrating, enhanced precipitation by the African Monsoon (Bosmans et al., 2015a; Tuenter et al., 2003). Insolation maxima (not only during i-104) caused heavy precipitation and thus increased river run-off also in southern Iberia (Joannin et al., 2011; Sierro et al., 2000), so that the Site U1387 $\delta{ }^{13} \mathrm{C}$ data might have picked-up a signal originating more from the western than the eastern Mediterranean Sea or even a more local one during cycle i-104. A local signal could be ENACW $\mathrm{sp}$ temporarily replacing MOW as bottom water mass keeping in mind that nowadays the upper MOW core is only 50-60 m thick above Site U1387 (Fig. 1). The observed benthic $\delta^{13} \mathrm{C}$ values of less than $0.6 \%$, which are in the modern $\delta^{13} C_{\text {DIC }}$ (DIC $=$ dissolved inorganic carbon) range for the $\mathrm{ENACW}_{\mathrm{sp}}$ along the western Iberian margin (A. Voelker, unpublished data), would support such a scenario. However, the downhole logging and core gamma-ray records of the Exp. 339 Sites recorded a strong contribution of river-transported clays to the sediments during insolation maxima (Lofi et al., submitted). The Site U1387 C/N data also indicates advection of terrestrial material (Fig. 5h). The estuaries of the Guadiana and Guadalquivir rivers, the two prominent rivers in the region, are located to the east of Site U1387 (Fig. 1a). Nowadays the only water mass flowing in east-west direction in the Gulf of Cadiz that could transport the clays from the estuaries to Site U1387 is the MOW. Consequently, an upper MOW branch must have existed and influenced Site U1387 during any of the insolation maxima, although we cannot exclude that the benthic $\delta^{13} \mathrm{C}$ signal contains a strong ENACW ${ }_{\text {sp }}$ contribution. A higher ENACW contribution would make the MOW waters less dense (Price and Baringer, 1994) and thus potentially neutrally buoyant already in the vicinity of the Faro 
Drift rather than near Cape São Vicente where the MOW undercurrent becomes buoyant today. In the future, combining hydrographic and sedimentological evidence from the different Sites drilled during Expedition 339 will allow better evaluating, if periods existed when the upper MOW might not have bathed the Faro Drift due to lateral or vertical displacement.

A well-ventilated and often fast flowing upper MOW (Fig. 5), on the other hand, marks insolation minima and the transition into the subsequent insolation maximum (Fig. 7b). The relationship between $\delta^{13} \mathrm{C}$ and insolation is independent of glacial/interglacial background climate conditions, so that periods of enhanced ventilation occurred during interglacial, glacial and transitional periods. Velocity increases, on the other hand, varied significantly between insolation minima, but were always associated with higher benthic $\delta^{13} \mathrm{C}$ values (Fig. 5). Some of the signals observed at Site U1387 must be related to conditions in the LIW because the Corsica margin record revealed that LIW velocity and ventilation increased during all MIS 5 transitions from insolation minimum to maximum (Toucanne et al., 2012).

The most prominent contourite layer of the studied interval is the one emplaced during MIS 31 when current velocity increased gradually, as clearly depicted by the mean gain size and $\ln (\mathrm{Zr} / \mathrm{Al})$ records, until it culminated in the sandiest part of the contourite, i.e. the one associated with highest bottom current velocity (Fig. 5). The timing of this layer coincided with the period of highest insolation during the last $1135 \mathrm{ky}$, i.e. i-cycle 100 (Fig. 7b), which appears to have influenced the intensity of the MOW velocity increase. This contourite layer is one of the few being formed during an interglacial period. A second interglacial contourite layer, which can now be included in the group of contourites related to low insolation forcing, is the youngest one that developed during the mid-Holocene (Llave et al., 2006; Toucanne et al., 2007; Voelker et al., 2006).

Within MIS 31 occurred a second distinct contourite layer, but this one coincided with the glacial inception of and transition into MIS 30 and represents a layer incorporating orbital and millennial-scale MOW oscillations (see Section 5.2). Another period of such mixed forcing of MOW velocity correlates with the transition into MIS 32 and most of MIS 32 when benthic $\delta^{13} \mathrm{C}$ remained high for a long period and MOW velocity was slightly increased throughout (Fig. 5). Short-termed maxima in MOW velocity responded, however, to millennial-scale forcing (see Section 5.2). MIS 34 is a similar, but more extreme case because of the strong millennial-scale overprinting on the insolation minimum related benthic $\delta^{13} \mathrm{C}$ high (Fig. 5).

Conditions during the late MIS 30 insolation minimum represent the third mode. Benthic $\delta^{13} \mathrm{C}$ values increased with the transition into the insolation minimum, but there was no response in MOW velocity with the $\ln (\mathrm{Zr} / \mathrm{Al})$ and wt.\% sand values even indicating a sluggish current (Fig. 5d). MOW velocity only increased in response to millennial-scale oscillations during the transition from the glacial maximum into MIS 29. The more sluggish upper MOW during glacial MIS 30 in comparison to MIS 32 and MIS 34 might be linked to the extended period of a lower sea level during MIS 30 (as for example reflected in the benthic $\delta^{18} \mathrm{O}$ record of Site U1308; Fig. 7a) than during the older glacial periods. This could have led to conditions more similar to MIS 2 when a denser MOW settled deeper in the water column, so that upper MOW circulation became sluggish and lower MOW velocity was enhanced (Llave et al., 2006; Rogerson et al., 2005; Voelker et al., 2006).

\subsection{Upper MOW responses to millennial-scale climate change}

Superimposed on the orbital-scale changes in upper MOW conditions are millennial-scale variations, i.e. short-term periods when velocity was enhanced as indicated by the $\ln (\mathrm{Zr} / \mathrm{Al})$ and wt.\% sand data (blue bars in Fig. 5). These increases in MOW velocity occurred 1) within interglacial MIS 33 and MIS 29; 2) during the stadial periods of the stadial/interstadial cycles marking the transitions from MIS 33 to MIS
32 and MIS 31 to MIS 30, respectively (see also Section 5.3); 3) during intervals of glacial MIS 32 and late MIS 30; and 4) during the glacial/interglacial transitions for MIS 32 to MIS 31 and MIS 30 to MIS 29, respectively. Whereas the general background state of the climate might differ during these periods, all enhanced circulation events have in common that the upper MOW was well ventilated (Fig. 5c) and that they occurred during periods of colder SST at Site U1387 (Fig. 6a, b). The relationship between cold surface waters and better MOW ventilation also holds for the extreme cold events during MIS 30 and MIS 32 (see Section 5.4) but only during the latter did velocity increase as well. The MIS 30 event even interrupts the period of poor ventilation related to the insolation maximum (Fig. 7). Flow velocity increases of the upper and lower MOW cores during North Atlantic ice-rafting events and/or Greenland stadials are well known from the last glacial cycle (Llave et al., 2006; Toucanne et al., 2007; Voelker et al., 2006) and have recently also been described for late MIS 6 and MIS 7 (Bahr et al., 2014; Singh et al., 2015). Voelker et al. (2006) linked these events to periods of enhanced deep convection in the western Mediterranean Sea and more recently, Toucanne et al. (2012) showed that better ventilation and faster flow also occurred at the level of the LIW in the western Mediterranean Sea. So both, WMDW and LIW, likely contributed to the same climatic response during the early Pleistocene events. Furthermore, Rogerson et al. (2012) estimated that buoyancy loss in the Strait of Gibraltar exchange and the interaction between MOW and eastern North Atlantic water masses also played a role. Especially the latter process might be linked to the intra-interglacial millennial-scale velocity increases that are observed for the first time.

\subsection{Surface water conditions during interglacial periods and their demise}

Although MIS 31 is sometimes described as a "super interglacial" (Melles et al., 2012) and in many records is warmer than the neighboring interglacial stages, MIS 31 is not standing out in the U1387 record. In the subtropical realm of the northern Gulf of Cadiz, MIS 31 and MIS 33 show a very similar SST record, not only in absolute values but also in shape (Fig. 6b). Both interglacials were associated with a long "plateau" of warm and relative stable SST, similar to what was recorded off the western Iberian margin during mid-Pleistocene interglacial MIS 11 and MIS 13 (Rodrigues et al., 2011). During MIS 31 SSTs remained above $21{ }^{\circ} \mathrm{C}$ for the whole interval from 1065 to $1091 \mathrm{ka}$, i.e. over both insolation maxima (Fig. 7), giving it a duration of 26 ky, just as long as MIS 11 and MIS 13a (both 27 ky; Tzedakis et al., 2012). The MIS 33 SST plateau $\left(\geq 20.5^{\circ} \mathrm{C}\right.$ ) lasted from 1100 to $1118 \mathrm{ka}$ and extended across the glacial inception of MIS 32. Restricted to the interglacial interval the SST plateau had a duration of $14 \mathrm{ky}$, putting it into the same category as MIS 5e (Tzedakis et al., 2012). The abrupt transition from glacial to interglacial SST observed for MIS 31 and MIS 33 as well as the millennial-scale oscillations during the transition from MIS 31 into MIS 30 also mirror conditions observed on the western Iberian margin for MIS 11 (Martrat et al., 2007; Rodrigues et al., 2011). During MIS 29, on the other hand, maximal SST values were about $2{ }^{\circ} \mathrm{C}$ colder (Fig. 6) and at a level similar to MIS 1 (Cacho et al., 2001). In contrast to the SST data, the G. bulloides $\delta^{18} \mathrm{O}$ record of Site U1387 shows relative stable conditions only during MIS 31, whereas both MIS 29 and MIS 33 recorded excursions to higher $\delta^{18} \mathrm{O}$ values (Fig. 6a) that might be linked to upwelling (colder temperatures) and/or salinity variations.

For placing the Site U1387 surface water signals into a wider regional context only a few records are currently available (Supplementary Fig. 2). Surface waters at Site U1387 and ODP Site $1058\left(31.7^{\circ} \mathrm{N}\right.$ $75.5^{\circ} \mathrm{W}$ ), from opposite sides of the North Atlantic basin, are linked through the Azores Current as previously shown by Voelker et al. (2010) for MIS 11 and MIS 13. During the early mid-Pleistocene Transition, however, the Gulf Stream planktonic $\delta^{18} \mathrm{O}$ record of Site 1058 (Weirauch et al., 2008) shows more variability than seen at the Portuguese margin, in particular during MIS 31 that is three-phased at Site 1058 and therefore more similar to Site U1387's benthic $\delta^{18} \mathrm{O}$ record. 
The surface water signals at Site U1387, likewise Site U1385 (Hodell et al., 2015), agree much more with conditions recorded along the North Atlantic Drift (DSDP Site 607: Lawrence et al., 2010/IODP Site U1313: Naafs et al., 2013) and its northern branch, the Irminger Current (IODP Site U1305: Hillaire-Marcel et al., 2011) (Supplementary Fig. 2). The strong correspondence of U1387 signals with North Atlantic Drift waters raises the question if during the early Pleistocene surface waters advected southward with the Portugal Current might have played a more dominant role on the Portuguese margin than those advected eastward with the Azores Current.

The Site U1387 records also agree well with Mediterranean Sea climate conditions. At Montalbano Jonico (Girone et al., 2013; Maiorano et al., 2010), warm surface waters mark MIS 31 with the increase in subtropical to tropical planktonic foraminifer species being nearly synchronous with the start of the SST plateau at Site U1387 (Supplementary Fig. 1). Furthermore, Mediterranean pollen records (Tenaghi Philippon: Tzedakis et al., 2006, Supplementary Fig. 2; Montalbano Jonico: Joannin et al., 2008; ODP Site 976, Alboran Sea: Joannin et al., 2011) recorded a long period with arboreal/ warmtemperate vegetation that is contemporary with the Site U1387 MIS 31 SST plateau. The Tenaghi Philippon pollen records also show a MIS 33 arboreal period synchronous with the U1387 SST maximum.

The demise of interglacial MIS 33 and MIS 31 is marked by stadial/interstadial oscillations, respectively, similar to those observed for midto-late Pleistocene interglacials such as MIS 13, MIS 11 and MIS 5 (e.g., Martrat et al., 2007; Rodrigues et al., 2011; Voelker et al., 2010). During the transition from MIS 33 to MIS 32 two stadial/interstadial cycles were recorded (more strongly in $\delta^{18} \mathrm{O}$ G. bulloides than SST; Fig. 6a, b), whereas the MIS 31 to MIS 30 transition experienced at least three oscillations. The second stadial/interstadial cycle of the latter transition could also be divided into two cycles because the small cooling seen in the interstadial SST record (but not G. bulloides $\delta^{18} \mathrm{O}$; Fig. 6) coincided with deteriorating oceanographic conditions in the subpolar North Atlantic (Fig. 7f, g; Grützner and Higgins, 2010; Hernández-Almeida et al., 2013). In the Gulf of Cadiz, the MIS 31/30 stadials recorded colder SST than their MIS 33/32 counterparts (Fig. 6b), which is probably related to the respective background state of the North Atlantic thermohaline circulation. The MIS 31 to MIS 30 transition occurred during a period of gradual AMOC slowdown as indicated by the decrease in the Iceland-Scotland Overflow strength at Site U1314 (Fig. 7f; Grützner and Higgins, 2010) and in the benthic $\delta^{13} \mathrm{C}$ values at Site U1308 (Fig. 7d; Hodell et al., 2008), whereas no such signals are seen for the MIS 33/32 interval.

\subsection{Glacial surface water variations}

Climate conditions during the three glacial stages in the Site U1387 record differed from one to the other (Fig. 6). MIS 30 and MIS 32 both recorded extreme cold episodes, whereas MIS 34, as also seen in other Mediterranean records (Girone et al., 2013; Tzedakis et al., 2006), was a relative warm glacial period. In contrast, the high latitude North Atlantic (e.g., IODP Site U1308: Hodell et al., 2008) recorded several icerafting events (Fig. 7d) and a strong reduction in the AMOC (Fig. 7e) during MIS 34 with only the pronounced ice-rafting event at the end of MIS 34 leading to a prolonged cooling in the Gulf of Cadiz (Fig. 7d, g). Thus, surface water conditions in the Gulf of Cadiz reveal a strong subtropical water influence and point to a more northern Polar Front position off the Iberian margin, i.e. conditions similar to those previously observed during MIS 14 (Rodrigues et al., 2011; Voelker et al., 2010), MIS 6 (Voelker and de Abreu, 2011) and some of the cold events of MIS 2 and MIS 3 (Salgueiro et al., 2014; Salgueiro et al., 2010; Voelker and de Abreu, 2011).

The coldest SST at Site U1387 occurred during MIS 32 when SST remained near or below $14{ }^{\circ} \mathrm{C}$ for a 3 ky period that marked the end of the MIS 33/32 stadial/interstadial oscillations (Fig. 6b). These SST are $\geq 1{ }^{\circ} \mathrm{C}$ colder than the SST recorded during Heinrich Stadial 1 in the
Gulf of Cadiz (Cacho et al., 2001) indicating that conditions during this period were more extreme and the Polar Front located far to the south (at least in the eastern North Atlantic). Surface-water cooling spreading from the high-latitude (Hodell et al., 2008; Toucanne et al., 2009) to the mid-latitude North Atlantic (Naafs et al., 2013; Hodell et al., 2015) and into the central Mediterranean Sea (Girone et al., 2013) and being contemporary with increased dust flux and aridity in the eastern Mediterranean (Fig. 6g, Larrasoana et al., 2003; Tzedakis et al., 2006, Supplementary Fig. 2) make the MIS 32 conditions comparable to the extremely cold Heinrich ice-rafting episodes recorded on the western Iberian margin during MIS 8, MIS 10 and MIS 12 (Martrat et al., 2007; Rodrigues et al., 2011; Voelker and de Abreu, 2011). A similar event occurred during MIS 30 (see below). At Site U1387, the transitions into and out of the MIS 32 extreme stadial event were abrupt indicating that the timing of the southward advance and northward retreat of the position of the Polar Front was comparable with the one observed for middle to late Pleistocene cooling events (Martrat et al., 2007; Rodrigues et al., 2011; Voelker and de Abreu, 2011; Voelker et al., 2010). After the initial warming, SST conditions in the Gulf of Cadiz remained, however, unstable with a stepwise transition to the full interglacial level (Figs. 6a, b; 7g), potentially linked to the AMOC strength variability depicted in the Site $\mathrm{U} 1308$ benthic $\delta^{13} \mathrm{C}$ data (Fig. 7d; Hodell et al., 2008).

Similar to MIS 32, the stadial/interstadial oscillations during the MIS $31 / 30$ transition culminated in an about 4 ky lasting, extreme stadial event (Fig. 6b) that was also chronicled at Site U1385 (Hodell et al., 2015). Like its MIS 32 counterpart, the event was associated with major surface-water cooling and deposition of ice-rafted debris in the high and mid-latitude North Atlantic (Fig. 7e, f; Hernández-Almeida et al., 2012; Hernández-Almeida et al., 2013; Hodell et al., 2008; Toucanne et al., 2009) as well as a cool and arid Mediterranean climate (Girone et al., 2013; Joannin et al., 2011) and increased Saharan dust flux off NW Africa (Fig. 6g; Tiedemann et al., 1994). Interestingly, both cold events recorded a short period of slightly warmer SST in the middle (Fig. 6b), which for the MIS 30 event is also seen in the Site U1313 record (Supplementary Fig. 2; Naafs et al., 2013). In the Gulf of Cadiz, such oscillations were already observed during Heinrich stadials 1 and 4 of the last glacial cycle (Voelker et al., 2006) and attributed to shortterm shifts in the latitudinal position of the Polar Front.

During MIS 30 the extreme stadial event was followed by a $8 \mathrm{ky}$ long period of relative warm surface waters, also evident in the Site U1385 planktonic $\delta^{18} \mathrm{O}$ record (Hodell et al., 2015), when SSTs were at a level similar to the MIS 31/30 interstadials and the middle of MIS 34 (Fig. 6b) revealing subtropical water influence. This warm period is observed in all locations influenced by Gulf Stream (Site 1058: Weirauch et al., 2008) and North Atlantic Drift waters (Sites 607/U1313: Lawrence et al., 2010; Naafs et al., 2013; Site U1314: Hernández-Almeida et al., 2012) but following modern oceanographic conditions the subtropical waters in the Gulf of Cadiz likely originated from the Azores Current. The end of MIS 30 was marked by slightly colder SST and more variable planktonic $\delta^{18} \mathrm{O}$ values pointing to less stable surface water conditions that were partially produced by the return of colder, iceberg-carrying surface waters to the subpolar North Atlantic (Fig. 7f, g; Hernández-Almeida et al., 2012).

\subsection{High plankton productivity periods}

At Site U1387 the total alkenone and wt.\% organic carbon records indicate three periods of increased (phyto)plankton productivity, two of which occurred during the early phases of the respective interglacial stage and the third during late glacial MIS 30 (Fig. 6). Nowadays, increased productivity in this region is associated either with westerlies inducing upwelling off Cape Santa Maria (Fig. 1a) or with stratified conditions during April to October (Navarro and Ruiz, 2006). Both are concomitant with lower SST (Navarro and Ruiz, 2006), in agreement with the Site U1387 SST record, especially during MIS 31 when the initial warming is followed by a period of slightly colder SST coinciding with 
the higher productivity (Fig. 6). At Site U1387 these intervals also recorded higher concentrations of terrestrial biomarkers (Fig. 6d) and terrestrial organic matter (higher $\mathrm{C} / \mathrm{N}$ values; Fig. $5 \mathrm{~h}$ ) that could have been transported with the westerlies to the Site and would thus corroborate upwelled nutrients as source for the increased productivity. Enhanced productivity and increased wind strength, inferred from the higher concentrations of terrestrial biomarkers, at the beginning of an interglacial stage was already observed in the western Iberian upwelling system during MIS 9, MIS 11 and MIS 13 (Rodrigues et al., 2011). On the other hand, the supply of terrestrial matter and nutrients supporting increased productivity could come from river run-off, in particular from the Guadiana and Guadalquivir Rivers (Fig. 1a). At present, nutrients provided by a higher discharge from the Guadalquivir River mostly affect the shelf waters north of the Huelva front and do not reach Site U1387 (Navarro and Ruiz, 2006), but this could have been different in the past. The early MIS 33 and MIS 31 productivity maxima occurred during insolation maxima that in southern Iberia are associated with increased rainfall and subsequently river discharge (Sierro et al., 2000). Higher precipitation during early MIS 31 is supported by the ODP Site 976 pollen record (Joannin et al., 2011), so that the interglacial productivity maxima at Site U1387 could result from a combination of nutrients provided by river discharge as well as upwelling. The late MIS 30 productivity increase, on the other hand, is probably more upwelling-related (wind-driven) because precipitation during this interval was low (Joannin et al., 2011), but Saharan dust flux was still high (Fig. 6g; Larrasoana et al., 2003; Tiedemann et al., 1994).

\section{Conclusions}

The early Pleistocene climate records of IODP Site U1387 revealed that the history of the upper MOW encompasses a complex interplay of orbital and millennial-scale forcing. Precession (insolation) forcing on MOW ventilation is now clearly established, not only by this study but also for other Expedition 339 Sites and time periods (e.g., Lebreiro et al., submitted; Singh et al., 2015). The impacts of insolation maxima (minima) were independent of glacial and interglacial climate conditions and mostly related to Mediterranean climate conditions as clearly demonstrated by the coincidence of sapropel layers in the eastern Mediterranean Sea and poor ventilation in the upper MOW. However, whereas insolation maxima always caused a sluggish upper MOW current, insolation minima vice versa did not necessarily lead to increases in MOW velocity. During the glacial MIS 30 insolation minimum upper MOW circulation remained sluggish revealing that background climate conditions effected velocity as well. Colder SST during millennial-scale climate oscillations, on the other hand, always led to short-term maxima in MOW velocity, in agreement with previous findings from the last glacial/interglacial cycle (Bahr et al., 2014; Llave et al., 2006; Toucanne et al., 2007; Voelker et al., 2006) and highlighting the important interplay between North Atlantic water masses and MOW (Rogerson et al., 2012).

In the northern Gulf of Cadiz interglacial MIS 31 was not associated with exceptionally warmer SST, although SSTs were about $2{ }^{\circ} \mathrm{C}$ warmer than during the Holocene. This interglacial period, however, stands out as a 26 ky-long interval of warm surface waters and for the development of a prominent contourite layer during insolation cycle i-100, one of the few contourite layers formed under interglacial climate conditions. Transitions into and out of the interglacial period were marked by millennial-scale SST oscillation making the surface water evolution during MIS 31 a mirror image of MIS 11 as recorded on the western Iberian margin (Rodrigues et al., 2011), even though orbital forcing differed between these two interglacial periods.

The early Pleistocene surface waters moreover experienced two periods of extremely cold SST that in their duration and climatic impact were comparable with the Heinrich events of the middle to late Pleistocene. These cold events were caused by conditions in the North Atlantic illustrating that also during the early Pleistocene the Polar Front was periodically pushed southward into the mid-latitudes.

Hydrographic conditions at Site U1387 revealed influences from Mediterranean and North Atlantic climates and that no glacial or interglacial period experienced the same conditions, in particular in regard to MOW velocity changes and thus the potential of forming contourite layers. It remains to be seen in the future if some of the climatic patterns observed during the MIS 29-34 interval also occurred during younger and older glacial/interglacial cycles, potentially independent of the dominant orbital cycle. Furthermore, data from the other Expedition 339 Sites under MOW influence are needed to verify if a sluggish bottom current at Site U1387 was related to MOW conditions or the replacement of MOW by ENACW.

Supplementary data to this article can be found online at http://dx. doi.org/10.1016/j.gloplacha.2015.08.015.

\section{Acknowledgments}

Funds provided by the Fundação para a Ciência e a Tecnologia (FCT; Portugal) to A.V. through the MOWCADYN project (PTDC/MAR-PRO/ 3761/2012) made this study possible. T.R. acknowledges her SFRH/BPD/ 66025/2009 fellowship from FCT and A.V. her Ciência 2007 and FCT Investigator 2014 researcher contracts. Additional funding for the XRF measurements was provided by the Deutsche Forschungsgemeinschaft (DFG) through grants BA 3809/4 to A.B. and RO 1113/6 to U.R.; the MARUM Research Center through Michal Kucera to A.R. and A.V. and by Carlota Escutia (Spanish Ministry of Science and Innovation CTM 2011-24079 project). Collection of the Iberia-Forams CTD data was made possible through the European Union 7th Framework Programme (FP7/20072013) under grant agreement no. 228344-EUROFLEETS (to A.V.). A.V. thanks Anne de Vernal and Claude Hillaire-Marcel for hosting her as guest scientist at GEOTOP-UQAM (Canada), which enabled her to photograph the foraminifer shells with GEOTOP's SEM. Henning Kuhnert (MARUM) and Michael Joachimski (Geozentrum Nordbayern) are acknowledged for their great help in obtaining the stable isotope data; sometimes within very short time periods. A.V., furthermore, appreciates the help provided by the Bremen Core Repository staff and students during the various sampling periods. This study uses samples provided by the Integrated Ocean Drilling Program (IODP; 2003-2013), now International Ocean Drilling Program (IODP; 2013-2023).

\section{References}

Ambar, I., 1983. A shallow core of Mediterranean Water off Western Portugal. Deep Sea Res. Part A 30, 677-680.

Ambar, I., Howe, M.R., 1979. Observations of the Mediterranean Outflow: 1. Mixing in the Mediterranean Outflow. Deep-Sea Res. 26, 535-554.

Ambar, I., Armi, L., Bower, A., Ferreira, T., 1999. Some aspects of time variability of the Mediterranean Water off south Portugal. Deep Sea Res., Part I 46, 1109-1136.

Ambar, I., Serra, N., Brogueira, M.J., Cabecadas, G., Abrantes, F., Freitas, P., Goncalves, C., Gonzalez, N., 2002. Physical, chemical and sedimentological aspects of the Mediterranean Outflow off Iberia. Deep-Sea Res. II Top. Stud. Oceanogr. 49, 4163-4177.

Bahr, A., Jiménez-Espejo, F.J., Kolasinac, N., Grunert, P., Hernández-Molina, F.J., Röhl, U., Voelker, A.H.L., Escutia, C., Stow, D.A.V., Hodell, D., Alvarez-Zarikian, C.A., 2014. Deciphering bottom current velocity and paleoclimate signals from contourite deposits in the Gulf of Cádiz during the last $140 \mathrm{kyr}$ : an inorganic geochemical approach. Geochem. Geophys. Geosyst. 15, 3145-3160. http://dx.doi.org/10.1002/ 2014GC005356.

Baringer, M.O., Price, J.F., 1997. Mixing and spreading of the Mediterranean Outflow. J. Phys. Oceanogr. 27, 1654-1677.

Billups, K., Scheinwald, A., 2014. Origin of millennial-scale climate signals in the subtropical North Atlantic. Paleoceanography 29, 612-627. http://dx.doi.org/10.1002/ 2014PA002641 (2014PA002641).

Bosmans, J.H.C., Drijfhout, S.S., Tuenter, E., Hilgen, F.J., Lourens, L.J., 2015a. Response of the North African summer monsoon to precession and obliquity forcings in the EC-Earth GCM. Clim. Dyn. 44, 279-297.

Bosmans, J.H.C., Drijfhout, S.S., Tuenter, E., Hilgen, F.J., Lourens, L.J., Rohling, E.J., 2015 b. Precession and obliquity forcing of the freshwater budget over the Mediterranean. Quat. Sci. Rev. 123, 16-30.

Bower, A.S., Serra, N., Ambar, I., 2002. Structure of the Mediterranean undercurrent and Mediterranean Water spreading around the southwestern Iberian Peninsula. J. Geophys. Res. 107, 25-1-25-19. http://dx.doi.org/10.1029/2001jc001007 (Document Number: 3161) 
Brambilla, E., Talley, L.D., Robbins, P.E., 2008. Subpolar mode water in the northeastern Atlantic: 2. Origin and transformation. J. Geophys. Res. 113. http://dx.doi.org/10.1029/ 2006jc004063 16 pages (Document Number: C04026).

Brassell, S.C., Eglinton, G., Marlowe, I.T., Pflaumann, U., Sarnthein, M., 1986. Molecular stratigraphy: a new tool for climatic assessment. Nature 320, 129-133.

Cabeçadas, G., Brogueira, M.J., Goncalves, C., 2002. The chemistry of Mediterranean Outflow and its interactions with surrounding waters. Deep-Sea Res. II Top. Stud. Oceanogr. 49, 4263-4270.

Cacho, I., Grimalt, J.O., Canals, M., Sbaffi, L., Shackleton, N.J., Schoenfeld, J., Zahn, R., 2001. Variability of the western Mediterranean Sea surface temperature during the last 25,000 years and its connection with the Northern Hemisphere climatic changes. Paleoceanography $16,40-52$.

Candela, J., 2001. Mediterranean Water and global circulation. In: Siedler, G., Church, J., Gould, J. (Eds.), Ocean Circulation and Climate-Observing and Modelling the Global Ocean. Academic Press, San Diego, London, pp. 419-429.

Clark, P.U., Archer, D., Pollard, D., Blum, J.D., Rial, J.A., Brovkin, V., Mix, A.C., Pisias, N.G., Roy, M., 2006. The Middle Pleistocene Transition: characteristics, mechanisms, and implications for long-term changes in atmospheric $\mathrm{pCO}_{2}$. Quat. Sci. Rev. 25, 3150-3184.

Criado-Aldeanueva, F., Garcia-Lafuente, J., Vargas, J.M., Del Rio, J., Vazquez, A., Reul, A., Sanchez, A., 2006. Distribution and circulation of water masses in the Gulf of Cadiz from in situ observations. Deep-Sea Res. II Top. Stud. Oceanogr. 53, 1144-1160.

de Lange, G.J., Thomson, J., Reitz, A., Slomp, C.P., Speranza Principato, M., Erba, E., Corselli, C., 2008. Synchronous basin-wide formation and redox-controlled preservation of a Mediterranean sapropel. Nat. Geosci. 1, 606-610.

Eglinton, T.I., Eglinton, G., 2008. Molecular proxies for paleoclimatology. Earth Planet. Sci. Lett. 275, 1-16.

Eglinton, G., Hamilton, R.J., Raphael, R.A., Gonzalez, A.G., 1962. Hydrocarbon constituents of the wax coatings of plant leaves: a taxonomic survey. Nature 193, 739-742.

Emeis, K.-C., Sakamoto, T., Wehausen, R., Brumsack, H.-J., 2000. The sapropel record of the eastern Mediterranean Sea-results of Ocean Drilling Program Leg 160. Palaeogeogr. Palaeoclimatol. Palaeoecol. 158, 371-395.

Emeis, K.-C., Schulz, H., Struck, U., Rossignol-Strick, M., Erlenkeuser, H., Howell, M.W., Kroon, D., Mackensen, A., Ishizuka, S., Oba, T., Sakamoto, T., Koizumi, I., 2003. Eastern Mediterranean surface water temperatures and $\delta^{18} \mathrm{O}$ composition during deposition of sapropels in the late Quaternary. Paleoceanography 18, 1005. http://dx.doi.org/ $10.1029 / 2000$ PA000617.

Expedition 339 Scientists, 2013. Site U1387. In: Stow, D.A.V., Hernández-Molina, F.J., Alvarez Zarikian, C.A., the. Expedition.339.Scientists (Eds.), Proceedings IODP Exp. 339: Mediterranean Outflow. Integrated Ocean Drilling Program Management International, Inc., Tokyo.

Faugères, J., Gonthier, E., Stow, D., 1984. Contourite drift molded by deep Mediterranean Outflow. Geology 12, 296-300.

Ferretti, P., Crowhurst, S.J., Hall, M.A., Cacho, I., 2010. North Atlantic millennial-scale climate variability 910 to $790 \mathrm{ka}$ and the role of the equatorial insolation forcing. Earth Planet. Sci. Lett. 293, 28-41.

Fiuza, A.F.G., Hamann, M., Ambar, I., del Rio, G.D., Gonzalez, N., Cabanas, J.M., 1998. Water masses and their circulation off western Iberia during May 1993. Deep Sea Res., Part I $45,1127-1160$.

Flood, R.D., Ducassou, E., submitted. Structure and variability of Mediterranean Outflow water flow recorded in contourite layers in the Gulf of Cadiz and west of Portugal. Marine Geology, (in review).

Garcia-Lafuente, J., Delgado, J., Criado-Aldeanueva, F., Bruno, M., del Rio, J., Miguel Vargas, J., 2006. Water mass circulation on the continental shelf of the Gulf of Cadiz. Deep-Sea Res. II Top. Stud. Oceanogr. 53, 1182-1197.

Girone, A., Capotondi, L., Ciaranfi, N., Di Leo, P., Lirer, F., Maiorano, P., Marino, M., Pelosi, N., Pulice, I., 2013. Paleoenvironmental changes at the lower Pleistocene Montalbano Jonico section (southern Italy): global versus regional signals. Palaeogeogr. Palaeoclimatol. Palaeoecol. 371, 62-79.

Grützner, J., Higgins, S.M., 2010. Threshold behavior of millennial scale variability in deep water hydrography inferred from a $1.1 \mathrm{Ma}$ long record of sediment provenance at the southern Gardar Drift. Paleoceanography 25, PA4204. http://dx.doi.org/10.1029/ 2009pa001873 17 pages.

Hernández-Almeida, I., Sierro, F.J., Cacho, I., Flores, J.A., 2012. Impact of suborbital climate changes in the North Atlantic on ice sheet dynamics at the mid-Pleistocene Transition. Paleoceanography 27, PA3214. http://dx.doi.org/10.1029/2011PA002209 14 pages.

Hernández-Almeida, I., Sierro, F.J., Flores, J.-A., Cacho, I., Filippelli, G.M., 2013 Palaeoceanographic changes in the North Atlantic during the mid-Pleistocene Transition (MIS 31-19) as inferred from planktonic foraminiferal and calcium carbonate records. Boreas 42, 140-159.

Hernández-Molina, F.J., Stow, D.A.V., Alvarez-Zarikian, C.A., Acton, G., Bahr, A., Balestra, B., Ducassou, E., Flood, R., Flores, J.-A., Furota, S., Grunert, P., Hodell, D., Jimenez-Espejo, F., Kim, J.K., Krissek, L., Kuroda, J., Li, B., Llave, E., Lofi, J., Lourens, L., Miller, M., Nanayama, F., Nishida, N., Richter, C., Roque, C., Pereira, H., Sanchez Goñi, M.F., Sierro, F.J., Singh, A.D., Sloss, C., Takashimizu, Y., Tzanova, A., Voelker, A., Williams, T., Xuan, C., 2014. Onset of Mediterranean Outflow into the North Atlantic. Science 344, 1244-1250.

Hillaire-Marcel, C., de Vernal, A., McKay, J., 2011. Foraminifer isotope study of the Pleistocene Labrador Sea, northwest North Atlantic (IODP Sites 1302/03 and 1305), with emphasis on paleoceanographical differences between its "inner" and "outer" basins. Mar. Geol. 279, 188-198.

Hodell, D.A., Channell, J.E.T., Curtis, J.H., Romero, O.E., Röhl, U., 2008. Onset of "Hudson Strait" Heinrich events in the eastern North Atlantic at the end of the Middle Pleistocene Transition ( 640 ka)? Paleoceanography 23. http://dx.doi.org/10.1029/ 2008PA001591 16.

Hodell, D., Crowhurst, S., Skinner, L., Tzedakis, P.C., Margari, V., Channell, J.E.T., Kamenov, G., Maclachlan, S., Rothwell, G., 2013. Response of Iberian Margin sediments to orbital and suborbital forcing over the past $420 \mathrm{ka}$. Paleoceanography 28, 185-199. http:// dx.doi.org/10.1002/palo.20017.

Hodell, D., Lourens, L., Crowhurst, S., Konijnendijk, T., Tjallingii, R., Jimenez-Espejo, F. Skinner, L., Tzedakis, P.C., Abrantes, F., Acton, G.D., Bahr, A., Balestra, B., LlaveBarranco, E., Carrara, G., Ducassou, E., Flood, R.D., Flores, J.-A., Furota, S., Grimalt, J. Grunert, P., Hernández-Molina, J., Kim, J.K., Krissek, L.A., Kuroda, J., Li, B., Lofi, J., Margari, V., Martrat, B., Miller, M.D., Nanayama, F., Nishida, N., Richter, C., Rodrigues, T., Rodríguez-Tovar, F.J., Roque, A.C.F., Sanchez-Goni, M.F., SierroSánchez, F.J., Singh, A.D., Sloss, C.R., Stow, D.A.V., Takashimizu, Y., Tzanova, A. Voelker, A., Xuan, C., Williams, T., Zarikian, C.A.A., 2015. A reference time scale for Site U1385 (Shackleton Site) on the SW Iberian Margin. Glob. Planet. Chang. 133, 49-64. http://dx.doi.org/10.1016/j.gloplacha.2015.07.002.

Hönisch, B., Hemming, N.G., Archer, D., Siddall, M., McManus, J.F., 2009. Atmospheric carbon dioxide concentration across the mid-Pleistocene Transition. Science 324 1551-1554.

Joannin, S., Ciaranfi, N., Stefanelli, S., 2008. Vegetation changes during the late early Pleistocene at Montalbano Jonico (Province of Matera, southern Italy) based on pollen analysis. Palaeogeogr. Palaeoclimatol. Palaeoecol. 270, 92-101.

Joannin, S., Bassinot, F., Nebout, N.C., Peyron, O., Beaudouin, C., 2011. Vegetation response to obliquity and precession forcing during the mid-Pleistocene Transition in Western Mediterranean region (ODP site 976). Quat. Sci. Rev. 30, 280-297.

Keigwin, L.D., 2002. Late Pleistocene-Holocene paleoceanography and ventilation of the Gulf of California. J. Oceanogr. 58, 421-432.

Kinder, T.H., Parrilla, G., 1987. Yes, some of the Mediterranean Outflow does come from great depth. J. Geophys. Res. 92, 2901-2906.

Larrasoana, J.C., Roberts, A.P., Rohling, E.J., Winklhofer, M., Wehausen, R., 2003. Three million years of monsoon variability over the northern Sahara. Clim. Dyn. 21, 689-698.

Laskar, J., Robutel, P., Joutel, F., Gastineau, M., Correia, A.C.M., Levrard, B., 2004. A longterm numerical solution for the insolation quantities of the Earth. Astron. Astrophys. 428, 261-285. http://dx.doi.org/10.1051/0004-6361:20041335.

Lawrence, K.T., Sosdian, S., White, H.E., Rosenthal, Y., 2010. North Atlantic climate evolution through the Plio-Pleistocene climate transitions. Earth Planet. Sci. Lett. 300, 329-342.

Lebreiro, S.M., Antón, L., Reguera, I., Fernández, M., Conde, E., Barrado, A.I., Yllera, A., submitted. Zooming into the Mediterranean Outflow moat during the 1.2-1.8 million years period (mid-Pleistocene) -- an approach by stable and radiogenic isotopes. Global and Planetary Change, (in revision).

Lisiecki, L.E., Raymo, M., 2005. A Pliocene-Pleistocene stack of 57 globally distributed benthic $\delta^{18} \mathrm{O}$ records. Paleoceanography 20, PA1003. http://dx.doi.org/10.1029/2004PA001071 17 pages.

Llave, E., Hernandez-Molina, F.J., Somoza, L., Diaz-del-Rio, V., Stow, D.A.V., Maestro, A. Dias, J.M.A., 2001. Seismic stacking pattern of the Faro-Albufeira contourite system (Gulf of Cadiz): a Quaternary record of paleoceanographic and tectonic influences. Mar. Geophys. Res. 22, 487-508.

Llave, E., Schönfeld, J., Hernandez-Molina, F.J., Mulder, T., Somoza, L., Diaz del Rio, V., Sanchez-Almazo, I., 2006. High-resolution stratigraphy of the Mediterranean Outflow contourite system in the Gulf of Cadiz during the late Pleistocene: the impact of Heinrich events. Mar. Geol. 227, 241-262.

Lofi, J., Voelker, A.H.L., Ducassou, E., Hernández-Molina, F.J., Sierro, F.J., Bahr, A., Galvani, A. Lourens, L., Pardo-Igúzquiza, E., Rodriguez-Tovar, F.J., Williams, T., submitted. Quaternary record in the Gulf of Cádiz and Portuguese contourite depositional systems. Marine Geology, (in revision).

Louarn, E., Morin, P., 2011. Antarctic Intermediate Water influence on Mediterranean sea water Outflow. Deep-Sea Res. I Oceanogr. Res. Pap. 58, 932-942.

Maiorano, P., Capotondi, L., Ciaranfi, N., Girone, A., Lirer, F., Marino, M., Pelosi, N., Petrosino, P., Piscitelli, A., 2010. Vrica-Crotone and Montalbano Jonico sections: a potential unit-stratotype of the Calabrian Stage. Episodes 33, 218-233.

Marchitto, T.M., Curry, W.B., Lynch-Stieglitz, J., Bryan, S.P., Cobb, K.M., Lund, D.C., 2014. Improved oxygen isotope temperature calibrations for cosmopolitan benthic foraminifera. Geochim. Cosmochim. Acta 130, 1-11.

Martrat, B., Grimalt, J.O., Shackleton, N.J., de Abreu, L., Hutterli, M.A., Stocker, T.F., 2007. Four climate cycles of recurring deep and surface water destabilizations on the Iberian Margin. Science 317, 502-507.

McClymont, E.L., Rosell-Melé, A., Haug, G.H., Lloyd, J.M., 2008. Expansion of subarctic water masses in the North Atlantic and Pacific oceans and implications for midPleistocene ice sheet growth. Paleoceanography 23, PA4214. http://dx.doi.org/10. 1029/2008PA001622 12 pages.

McClymont, E.L., Sosdian, S.M., Rosell-Melé, A., Rosenthal, Y., 2013. Pleistocene seasurface temperature evolution: early cooling, delayed glacial intensification, and implications for the mid-Pleistocene climate transition. Earth Sci. Rev. 123, 173-193.

McCorkle, D.C., Corliss, B.H., Farnham, C.A., 1997. Vertical distributions and stable isotopic compositions of live (stained) benthic foraminifera from the North Carolina and California continental margins. Deep-Sea Res. I Oceanogr. Res. Pap. 44, 983-1024.

Medina-Elizalde, M., Lea, D.W., 2005. The mid-Pleistocene Transition in the tropical Pacific. Science 310, 1009-1012.

Melles, M., Brigham-Grette, J., Minyuk, P.S., Nowaczyk, N.R., Wennrich, V., DeConto, R.M., Anderson, P.M., Andreev, A.A., Coletti, A., Cook, T.L., Haltia-Hovi, E., Kukkonen, M. Lozhkin, A.V., Rosén, P., Tarasov, P., Vogel, H., Wagner, B., 2012. 2.8 million years of Arctic climate change from Lake El'gygytgyn, NE Russia. Science 337, 315-320.

Millot, C., Candela, J., Fuda, J.-L., Tber, Y., 2006. Large warming and salinification of the Mediterranean Outflow due to changes in its composition. Deep-Sea Res. I Oceanogr. Res. Pap. 53, 656-666.

Mudelsee, M., Schulz, M., 1997. The mid-Pleistocene climate transition: onset of 100 ka cycle lags ice volume build-up by 280 ka. Earth Planet. Sci. Lett. 151, 117-123.

Müller, P.J., Kirst, G., Ruhland, G., von Storch, I., Rosell-Melé, A., 1998. Calibration of the alkenone paleotemperature index Uk'37 based on core-tops from the eastern South 
Atlantic and the global ocean $\left(60^{\circ} \mathrm{N}-60^{\circ} \mathrm{S}\right)$. Geochim. Cosmochim. Acta 62 , 1757-1772.

Naafs, B.D.A., Hefter, J., Stein, R., 2013. Millennial-scale ice rafting events and Hudson Strait Heinrich(-like) Events during the late Pliocene and Pleistocene: a review. Quat. Sci. Rev. 80, 1-28.

Naish, T., Powell, R., Levy, R., Wilson, G., Scherer, R., Talarico, F., Krissek, L., Niessen, F., Pompilio, M., Wilson, T., Carter, L., DeConto, R., Huybers, P., McKay, R., Pollard, D. Ross, J., Winter, D., Barrett, P., Browne, G., Cody, R., Cowan, E., Crampton, J., Dunbar, G., Dunbar, N., Florindo, F., Gebhardt, C., Graham, I., Hannah, M., Hansaraj, D., Harwood, D., Helling, D., Henrys, S., Hinnov, L., Kuhn, G., Kyle, P., Laufer, A., Maffioli, P., Magens, D., Mandernack, K., McIntosh, W., Millan, C., Morin, R., Ohneiser, C., Paulsen, T., Persico, D., Raine, I., Reed, J., Riesselman, C., Sagnotti, L., Schmitt, D. Sjunneskog, C., Strong, P., Taviani, M., Vogel, S., Wilch, T., Williams, T., 2009 Obliquity-paced Pliocene West Antarctic ice sheet oscillations. Nature 458, 322-328.

Navarro, G., Ruiz, J., 2006. Spatial and temporal variability of phytoplankton in the Gulf of Cadiz through remote sensing images. Deep-Sea Res. II Top. Stud. Oceanogr. 53, $1241-1260$

Peliz, A., Dubert, J., Santos, A.M.P., Oliveira, P.B., Le Cann, B., 2005. Winter upper ocean circulation in the Western Iberian Basin-fronts, eddies and poleward flows: an overview. Deep-Sea Res. I Oceanogr. Res. Pap. 52, 621-646.

Peliz, A., Dubert, J., Marchesiello, P., Teles-Machado, A., 2007. Surface circulation in the Gulf of Cadiz: model and mean flow structure. J. Geophys. Res. 112. http://dx.doi. org/10.1029/2007JC004159 20 pages, C11015.

Peliz, A., Marchesiello, P., Santos, A.M.P., Dubert, J., Teles-Machado, A., Marta-Almeida, M. Le Cann, B., 2009. Surface circulation in the Gulf of Cadiz: 2. Inflow-outflow coupling and the Gulf of Cadiz Slope Current. J. Geophys. Res. 114, C03011. http://dx.doi.org/ 10.1029/2008JC004771 16 pages.

Price, J.F., Baringer, M.O., 1994. Outflows and deep water production by marginal seas. Prog. Oceanogr. 33, 161-200.

Raffi, I., Backman, J., Fornaciari, E., Pälike, H., Rio, D., Lourens, L., Hilgen, F., 2006. A review of calcareous nannofossil astrobiochronology encompassing the past 25 million years. Quat. Sci. Rev. 25, 3113-3137.

Rathburn, A.E., Corliss, B.H., Tappa, K.D., Lohmann, K.C., 1996. Comparisons of the ecology and stable isotopic compositions of living (stained) benthic foraminifera from the Sulu and South China Seas. Deep-Sea Res. I Oceanogr. Res. Pap. 43, 1617-1646.

Relvas, P., Barton, E.D., 2002. Mesoscale patterns in the Cape São Vicente (Iberian Peninsula) upwelling region. J. Geophys. Res. 107, 28-1-28-23. http://dx.doi.org/10.1029/ 2000jc000456 (Document Number: 3164).

Rios, A.F., Perez, F.F., Fraga, F., 1992. Water masses in the Upper and Middle North-Atlantic Ocean east of the Azores. Deep Sea Res. Part A 39, 645-658.

Rodrigues, T., Voelker, A.H.L., Grimalt, J.O., Abrantes, F., Naughton, F., 2011. Iberian Margin sea surface temperature during MIS 15 to 9 (580-300 ka): glacial suborbital variability versus interglacial stability. Paleoceanography 26, PA1204. http://dx.doi.org/10. 1029/2010PA001927 16 pages.

Rogerson, M., Rohling, E.J., Weaver, P.P.E., Murray, J.W., 2005. Glacial to interglacial changes in the settling depth of the Mediterranean Outflow plume. Paleoceanography 20. http://dx.doi.org/10.1029/2004PA001106 12 pages, (Document Number: PA3007).

Rogerson, M., Rohling, E.J., Bigg, G.R., Ramirez, J., 2012. Paleoceanography of the AtlanticMediterranean exchange: overview and first quantitative assessment of climatic forcing. Rev. Geophys. 50, RG2003. http://dx.doi.org/10.1029/2011RG000376 32 pages.

Rohling, E.J., Gieskes, W.W.C., 1989. Late Quaternary changes in Mediterranean intermediate water density and formation rate. Paleoceanography 4, 531-545.

Roque, C., Duarte, H., Terrinha, P., Valadares, V., Noiva, J., Cachão, M., Ferreira, J., Legoinha, P. Zitellini, N., 2012. Pliocene and Quaternary depositional model of the Algarve margin contourite drifts (Gulf of Cadiz, SW Iberia): seismic architecture, tectonic control and paleoceanographic insights. Mar. Geol. 303-306, 42-62.

Rossignol-Strick, M., 1985. Mediterranean Quaternary sapropels, an immediate response of the African monsoon to variations of insolation. Palaeogeogr. Palaeoclimatol. Palaeoecol. 49, 237-263.

Russon, T., Elliot, M., Sadekov, A., Cabioch, G., CorrËge, T., De Deckker, P., 2011. The midPleistocene Transition in the subtropical southwest Pacific. Paleoceanography 26 PA1211. http://dx.doi.org/10.1029/2010pa002019 13 pages.

Salgueiro, E., Voelker, A.H.L., de Abreu, L., Abrantes, F., Meggers, H., Wefer, G., 2010. Temperature and productivity changes off the western Iberian margin during the last 150 ky. Quat. Sci. Rev. 29, 680-695.

Salgueiro, E., Naughton, F., Voelker, A.H.L., de Abreu, L., Alberto, A., Rossignol, L., Duprat, J. Magalhães, V.H., Vaqueiro, S., Turon, J.L., Abrantes, F., 2014. Past circulation along the western Iberian margin: a time slice vision from the Last Glacial to the Holocene. Quat. Sci. Rev. 106, 316-329.

Scherer, R.P., Bohaty, S.M., Dunbar, R.B., Esper, O., Flores, J.A., Gersonde, R., Harwood, D.M. Roberts, A.P., Taviani, M., 2008. Antarctic records of precession-paced insolation-driven warming during early Pleistocene Marine Isotope Stage 31. Geophys. Res. Lett. 35 http://dx.doi.org/10.1029/2007gl032254 5 pages, (Document Number: L03505).

Schlitzer, R., 2014. Ocean Data View. http://odv.awi.de.

Schmiedl, G., Mitschele, A., Beck, S., Emeis, K.-C., Hemleben, C., Schulz, H., Sperling, M. Weldeab, S., 2003. Benthic foraminiferal record of ecosystem variability in the eastern Mediterranean Sea during times of sapropel S5 and S6 deposition. Palaeogeogr Palaeoclimatol. Palaeoecol. 190, 139-164.

Schönfeld, J., 1997. The impact of the Mediterranean Outflow water (MOW) on benthic foraminiferal assemblages and surface sediments at the southern Portuguese continental margin. Mar. Micropaleontol. 29, 211-236.

Schönfeld, J., 2001. Benthic foraminifera and pore-water oxygen profiles: a re-assessment of species boundary conditions at the western Iberian margin. J. Foraminifer. Res. 31, 86-107.
Schönfeld, J., 2002. Recent benthic foraminiferal assemblages in deep high-energy environments from the Gulf of Cadiz (Spain). Mar. Micropaleontol. 44, 141-162.

Sierro, F.J., Flores, J.A., Baraza, J., 1999. Late glacial to recent paleoenvironmental changes in the Gulf of Cadiz and formation of sandy contourite layers. Mar. Geol. 155, 157-172.

Sierro, F.J., Ledesma, S., Flores, J.-A., Torrescusa, S., del Olmo, W.M., 2000. Sonic and gamma-ray astrochronology: cycle to cycle calibration of Atlantic climatic records to Mediterranean sapropels and astronomical oscillations. Geology 28, 695-698.

Singh, A.D., Rai, A.K., Tiwari, M., Naidu, P.D., Verma, K., Chaturvedi, M., Niyogi, A., Pandey, D., 2015. Fluctuations of Mediterranean Outflow water circulation in the Gulf of Cadiz during MIS 5 to 7: evidence from benthic foraminiferal assemblage and stable isotope records. Glob. Planet. Chang. 133, 125-140. http://dx.doi.org/10.1016/j.gloplacha. 2015.08.005.

Sousa, F.M., Bricaud, A., 1992. Satellite-derived phytoplankton pigment structures in the Portuguese upwelling area. J. Geophys. Res. 97, 11343-11356.

Stein, R., 1991. Accumulation of organic carbon in marine sediments-results from the Deep Sea Drilling Project/Ocean Drilling Program (DSDP/ODP). Springer-Verlag, Berlin Heidelberg.

Stow, D.A.V., Hernández-Molina, F.J., Alvarez Zarikian, C.A., the Expedition 339 Scientists, 2013. Proceedings IODP Exp, 339:Mediterranean Outflow. In: Stow, D.A.V. Hernández-Molina, F.J., Alvarez Zarikian, C.A., the Expedition 339 Scientists (Eds.), Integrated Ocean Drilling Program Management International, Inc., Tokyo. http://dx. doi.org/10.2204/iodp.proc.339.2013.

Teitler, L., Florindo, F., Warnke, D.A., Filippelli, G.M., Kupp, G., Taylor, B., 2015. Antarctic Ice Sheet response to a long warm interval across Marine Isotope Stage 31: a crosslatitudinal study of iceberg-rafted debris. Earth Planet. Sci. Lett. 409, 109-119.

Tiedemann, R., Sarnthein, M., Shackleton, N.J., 1994. Astronomic timescale for the Pliocene Atlantic $\delta^{18} \mathrm{O}$ and dust flux records of Ocean Drilling Program site 659. Paleoceanography 9, 619-638.

Toucanne, S., Mulder, T., Schoenfeld, J., Hanquiez, V., Gonthier, E., Duprat, J., Cremer, M., Zaragosi, S., 2007. Contourites of the Gulf of Cadiz: a high-resolution record of the paleocirculation of the Mediterranean Outflow water during the last 50,000 years. Palaeogeogr. Palaeoclimatol. Palaeoecol. 246, 354-366.

Toucanne, S., Zaragosi, S., Bourillet, J.F., Gibbard, P.L., Eynaud, F., Giraudeau, J., Turon, J.L., Cremer, M., Cortijo, E., Martinez, P., Rossignol, L., 2009. A 1.2 Ma record of glaciation and fluvial discharge from the West European Atlantic margin. Quat. Sci. Rev. 28, 2974-2981.

Toucanne, S., Jouet, G., Ducassou, E., Bassetti, M.-A., Dennielou, B., Angue Minto'o, C.M., Lahmi, M., Touyet, N., Charlier, K., Lericolais, G., Mulder, T., 2012. A 130,000-year record of Levantine Intermediate Water flow variability in the Corsica trough, western Mediterranean Sea. Quat. Sci. Rev. 33, 55-73.

Tripati, A.K., Roberts, C.D., Eagle, R.A., 2009. Coupling of $\mathrm{CO}_{2}$ and ice sheet stability over major climate transitions of the last 20 million years. Science 326, 1394-1397.

Tuenter, E., Weber, S.L., Hilgen, F.J., Lourens, L.J., 2003. The response of the African summer monsoon to remote and local forcing due to precession and obliquity. Glob. Planet. Chang. 36, 219-235.

Tzedakis, P.C., Hooghiemstra, H., Palike, H., 2006. The last 1.35 million years at Tenaghi Philippon: revised chronostratigraphy and long-term vegetation trends. Quat. Sci. Rev. 25, 3416-3430.

Tzedakis, P.C., Raynaud, D., McManus, J.F., Berger, A., Brovkin, V., Kiefer, T., 2009. Interglacial diversity. Nat. Geosci. 2, 751-755.

Tzedakis, P.C., Wolff, E.W., Skinner, L.C., Brovkin, V., Hodell, D.A., McManus, J.F., Raynaud, D., 2012. Can we predict the duration of an interglacial? Clim. Past 8, 1473-1485.

Villanueva, J., Grimalt, J.O., Cortijo, E., Vidal, L., Labeyrie, L., 1997. A biomarker approach to the organic matter deposited in the North Atlantic during the last climatic cycle. Geochim. Cosmochim. Acta 61, 4633-4646.

Voelker, A.H.L., de Abreu, L., 2011. A review of abrupt climate change events in the northeastern Atlantic Ocean (Iberian Margin): latitudinal, longitudinal and vertical gradients. In: Rashid, H., Polyak, L., Mosley-Thompson, E. (Eds.), Abrupt Climate Change: Mechanisms, Patterns, and Impacts. AGU, Washington, D.C., pp. 15-37.

Voelker, A.H.L., Lebreiro, S.M., Schönfeld, J., Cacho, I., Erlenkeuser, H., Abrantes, F., 2006. Mediterranean Outflow strengthening during northern hemisphere coolings: a salt source for the glacial Atlantic? Earth Planet. Sci. Lett. 245, 39-55.

Voelker, A.H.L., Rodrigues, T., Billups, K., Oppo, D., McManus, J., Stein, R., Hefter, J., Grimalt, J.O., 2010. Variations in mid-latitude North Atlantic surface water properties during the mid-Brunhes (MIS 9-14) and their implications for the thermohaline circulation. Clim. Past 6, 531-552. http://dx.doi.org/10.5194/cp-6-531-2010.

Voelker, A.H.L., Jimenez-Espejo, F.J., Bahr, A., Acton, G.D., Rebotim, A., Salgueiro, E., Röhl, U., Escutia, C., 2014. Mediterranean Outflow water changes in the Gulf of Cadiz during the mid-Pleistocene Transition-the role of insolation. In: van Rooij, D., Rüggeberg, A. (Eds.), Book of Abstracts. 2nd Deep-Water Circulation Congress: The Contourite Logbook. Ghent University, Department of Geology and Soil Science-Vlaams Instituut voor de Zee-Flanders Marine Institute (VLIZ), Oostende, Belgium, pp. 29-30 (Ghent, Belgium, 10-12 September 2014. VLIZ Special Publication 69)

Voelker, A.H.L., Colman, A., Olack, G., Waniek, J.J., Hodell, D., 2015. Oxygen and hydrogen isotope signatures of northeast Atlantic water masses. Deep-Sea Res. II Top. Stud. Oceanogr. 116, 89-106.

Weirauch, D., Billups, K., Martin, P., 2008. Evolution of millennial-scale climate variability during the Mid Pleistocene. Paleoceanography 23, PA3216. http://dx.doi.org/10.1029/ 2007PA001584 16 pages.

Wilson-Finelli, A., Chandler, G.T., Spero, H.J., 1998. Stable isotope behavior in paleoceanographically important benthic foraminifera; results from microcosm culture experiments. J. Foraminifer. Res. 28, 312-320. 